\title{
An Analysis of Spatial Relation Predicates in U.S. Geological Survey Feature Definitions
}

\author{
accumulation \\ along alongside \\ a rea a round a side \\ bordered bored botom breaks broken built \\ ca rry cast ca us ed cavity change characterized charge chartered collection compos ed \\ connecting cons is ting cons tructed \\ contains control \\ covered \\ designated \\ depression \\ discharging \\ equipped erected established exit expanse extending \\ fitted fanking floated flow fue follow force formed fortifed foul fronted functioning \\ genera ted going group held higher holding identifed including incorported indica ting intended interrupts \\ inters ection inundated is sues joined junction juris diction jutting kept known la id la \\ loca ted lowered lying maintained mass matera meas ured \\ opening \\ passage \\ projecting provided \\ raise \\ referenced \\ removed \\ serving \\ subject subteranean summit sunk support S Urfa Ce surrounded

\section{used}

Open-File Report 2011-1235 
Cover graphic: Word cloud. 


\section{An Analysis of Spatial Relation Predicates in U.S. Geological Survey Feature Definitions}

By Holly K. Caro and Dalia E. Varanka

Open-File Report 2011-1235 


\section{U.S. Department of the Interior \\ KEN SALAZAR, Secretary \\ U.S. Geological Survey \\ Marcia K. McNutt, Director}

U.S. Geological Survey, Reston, Virginia: 2011

Revised and reprinted: 2011

For more information on the USGS - the Federal source for science about the Earth, its natural and living resources, natural hazards, and the environment, visit http://www.usgs.gov or call 1-888-ASK-USGS.

For an overview of USGS information products, including maps, imagery, and publications, visit http://www.usgs.gov/pubprod

Any use of trade, product, or firm names is for descriptive purposes only and does not imply endorsement by the U.S. Government.

Although this report is in the public domain, permission must be secured from the individual copyright owners to reproduce any copyrighted materials contained within this report.

Suggested citation:

Caro, H.K., and Varanka, D.E., 2011, An analysis of spatial relation predicates in U.S. Geological Survey feature definitions: U.S. Geological Survey Open-File Report 2011-1235, 37 p. 


\section{Contents}

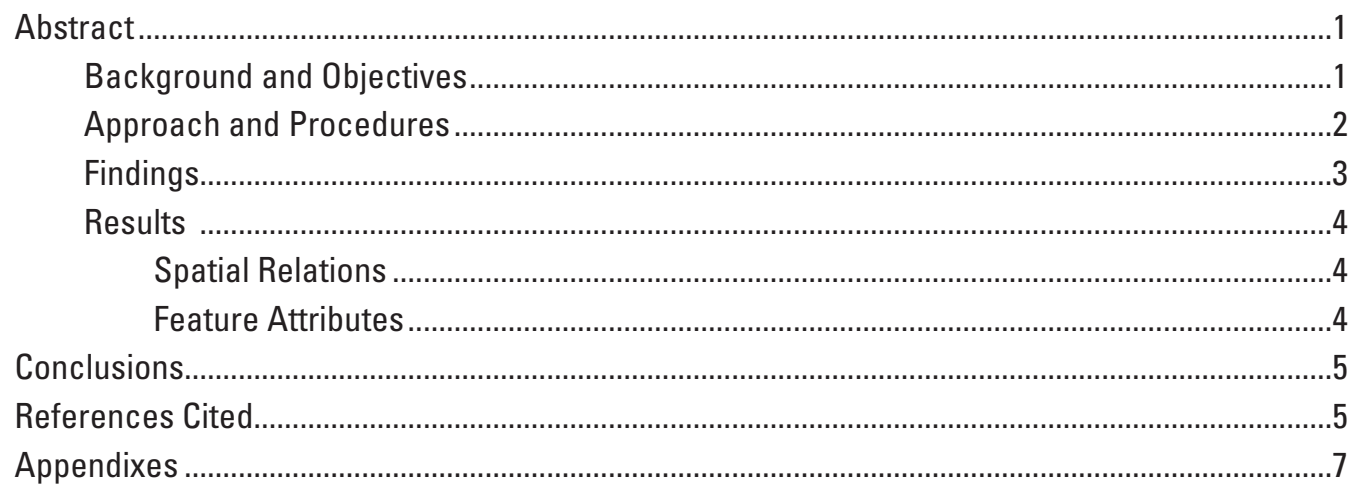

\section{Tables}

Table 1. Verb/preposition pairs functioning as predicates in feature term glossaries..................4 



\title{
An Analysis of Spatial Relation Predicates in U.S. Geological Survey Feature Definitions
}

\author{
Holly K. Caro and Dalia E. Varanka
}

\begin{abstract}
The Semantic Web uses a data model called a triple, which consists of a subject - predicate - object structure. When represented as triples, geospatial data require a spatial relation term to serve as the predicate linking two spatial features. This document summarizes the approaches and procedures used during the identification of spatial relationships common between topographic features using terms from topographic data standards. This project identified verb-predicate arguments that could be used in the creation of data triples and ontologies for The National Map of the U.S. Geological Survey and also investigated the possibility of deriving ontology from predefined textual definitions. The primary purpose of this report is to present the data used for subsequent analysis. A summary of terms organized by basic categories is provided.

Keywords: semantic technology, geospatial relations, topographic data
\end{abstract}

\section{Background and Objectives}

One of the prominent issues facing the field of geospatial information science is the design and implications of the emergent Semantic Web, coordinated through the World Wide Web Consortium (W3C) (Berners-Lee and others, 2001; W3C, 2010). The Semantic Web is a vision and implementation of linked data in a network graph that assists knowledge formation. The data model to construct this graph is called Resource Description Framework (RDF) and is formed by triples consisting of two nodes and an edge. Triples are conceptually similar to the subject - predicate — object syntax of simple sentence structures (Beckett, 2004). Triples hold promise for geographic information science modeling for many reasons, including greater flexibility and efficient analysis (Egenhofer, 2002). Logical axioms programmed as properties of the triples enable reasoning algorithms called ontologies to regulate the association between feature class types and their data instances.

Spatial relation representation assumes variable forms, including cognitive, linguistic, topological, and geometric. Topological relations were researched broadly and formalized in the 1990s, largely based on the 9-intersection model of binary relations applying to the interior, boundary, and exteriors of point, line, and area type objects (Egenhofer and Franzosa, 1991; Egenhofer and Herring, 1991). In the field of cognition and linguistics, some important publications on spatial information theory reference spatial relations. These publications focused on figure-ground alignment to analyze location and motion (Talmy, 1983), prepositions (Herskovits, 1986), and spatial reference systems (Levinson, 2003). Geographers cultivated these sources for ways to bridge formal models of spatial relations developed for geographic information systems (GIS) and natural language expressions to make these operations easier to understand and use in GIS (Shariff and others, 1998). Hirtle and Frank (1997) addressed spatial structure, boundaries, and change for similar reasons. A body of research emerged that established a basis for the semantics of geographic spatial relations. Although the work was developed for the user of the relational database model in GIS, this model is intuitively suited and being tested for representation in RDF triples.

Research results based on the 9-intersection model of topological spatial relations resulted in the establishment of eight standard spatial relations by the Open Geospatial Consortium (OGC); equals, disjoint, intersects, touches, crosses, within, contains, and overlaps (International Organization for Standardization, 2001). This standard was adapted to SPARQL Protocol and RDF Query Language (SPARQL) queries of geospatial ontology triples (Perry and Herring, 2010; W3C, 2008). Though this standard serves as an important foundation, the scope of the work is topologically specific, whereas topographic data and scientific modeling uses a broader range of spatial relation concepts. The subject of this report is the presentation of data used in the identification and on-going analysis of geospatial feature relations in topographic science as applied to semantic triples. Such terms are not quantitatively described, but operate based on cognitive and linguistic structures. For example, prepositions are terms that express a relation or location and typically govern another word or element in the clause. Prepositions are thus key terms for examining spatial relations between statement subjects and objects.

The approach used in this analysis also may prove useful to the development of text mining approaches for automated 
information extraction, or in comparing the ways that human interpretation of written definitions may differ from automated approaches. The discrepancies between the practical use of natural language and machine representation become evident when using this approach, and may present an outline as to how to resolve certain problems; for example, the further refinement of particular natural language phrasings to better ascertain the underlying semantics. This work should be viewed as a potential starting point for further investigation into the capabilities and intended functions of map ontologies and the ways that textual information may be used along with visual map displays, such as search functionality, or other semantic web technology applications.

\section{Approach and Procedures}

The approach to analyze spatial relations for topographic data triple predicates draws verb-predicate spatial relationships from textual definitions created and used by the U.S. Geological Survey (USGS) and its partners. These are the Spatial Data Transfer Standard (SDTS), Digital Line Graph Standards (DLG), and Geonames (U.S. Geological Survey, 2010; U.S. Board on Geographic Names, 2010). Similar approaches have been previously used by Mizen and others (2005) and Kokla and Kavouras (2005). The analysis was interpreted by native English language speakers, with the help of a dictionary. The data for this work are presented in appendixes.

The electronic tools used to locate, organize, and study the spatial relations within the text of this study primarily involved concordance and spreadsheet software. The concordance software was used to facilitate the easy sorting and display of a corpus of text by word (Watt, 2009a). The results allowed for textual analysis of trends in single word usage throughout text.

Attempts at analyzing predicates uncovered major limitations in the concordance software and most of the work was subsequently completed manually. One such limitation was the mechanism used for sorting. The concordance sorts a text based on an exact word match, an instance of a word irrelevant of its variant forms, such as different tense or person. A lemmatizer was provided with the program, where lemmas function as the head word for a related set of words that vary grammatically, but the predefined list of words in the lemmatizer is limited. While customization is possible, each new word or set of words has to be manually entered into the system. Some additional limitations of the use of predefined sets in the lemmatizer are that its use requirs manually checking outputs created with each sort. Most of the limitations are understandably caused because the lemmatizer works on character matching in the words, and does not tag for parts of speech. Ambiguous noun/adjective forms occur within the predefined sets (for example, "know, known", "do, done"), and there are no present participle forms currently included in the lemmatizer. Adding or correcting these features would have created an additional time commitment in using the lemmatizer for studies such as these. With limited datasets, such as those used in this analysis, entering the lemmas could take as long as manually identifying them, though for an analysis of larger datasets, customization and use of the lemmatizer would be beneficial. Additionally, some of the entries already programmed into the lemmatizer were related systematically, though not true lemmas (for example, "good, better, best"). Thus, the problem of exact word match would have still existed, even with its use. The set of "bear, bore, born, borne" is predefined, though most of the words carry multiple meanings and may not refer in any one use to the root verb "bear"- this would defeat the point of sorting them, because a human will still have to manually recheck and sort the results for accuracy. The online documentation discloses these aspects of the software in the section about the lemmatizer, concerning an example about the ambiguous word "lay." "Since human language is not a wholly rational construct, there is no general remedy for this issue except vigilance" (Watt, 2009b). It is important to note that many systems devoted to processing natural language currently experience similar pitfalls, and these issues are more often than not the product of naturally occurring inconsistencies and idiosyncrasies in natural language.

Microsoft Excel was used to store and sort the resulting tables of information to view the use of recurrent predicate spatial relations for a final analysis. Information was stored in a four column format. The first column represents the defined term, and the second, third, and fourth columns resemble the subject-predicate-object of the triple, in which the third column stores the identified verb and preposition (predicate) pair under examination. The subjects/objects found in the second and fourth columns store the relative parts of the definition appearing before and after the predicate to lend context to the use of the spatial relation in the definition. While completing the spreadsheet, a fifth column was used to record notes concerning the data.

Because natural language is a social and communicative tool that has not been (or cannot be) reduced to a system fully understood and correctly processed by computer automation, the intuition and understanding of a linguist whose first and native language is English also were used, though the method would be valid in other languages as well. In the case of this piece of research, the linguist also was the primary analyst responsible for processing, recording, and reporting the data.

The DLG and National Hydrography Dataset (NHD) glossaries are based on the feature types compiled from years of repeated field survey validation by cartographers (E.L. Usery, oral commun., 2010; U.S. Geological Survey, 1984). The SDTS feature list was developed by committees of representatives from partnering organizations and so has a wider scope of included features than those of topographic data. The Geographic Names Information System (GNIS) list originally was compiled from feature types shown on USGS topographical maps, but has added partner and volunteer contributions since 1987 (Orth and Payne, 1997). For each set of definitions, the entries were retrieved online and copied to a 
plain text document that would be compatible for use with the concordance.

The analysis involved reading each definition and interpreting any verb and preposition pairs within the definition. These pairs were then recorded on a spreadsheet. To find relevant spatial relations, both verbs and prepositions were examined independently and then analyzed for any relevant semantic relation with a counterpart. Then, the concordance was used to proceed through the definitions in the text document word by word to identify and analyze any verbs or prepositions that may have been missed in the initial reading. This step was critical in identifying secondary spatial relations that may have escaped initial analysis when overshadowed by a more prominent verb and preposition pair. Viewing verbs and prepositions with the concordance also allowed for analysis and understanding of word use trends throughout the text; for example, it became evident if a given verb seemed to favor usage with a particular preposition or set of prepositions, and thereby allowed for a supposition of an intended verb or preposition if a definition was written with either omitted.

\section{Findings}

A total of 668 feature term definitions were examined. In several instances, it was discovered that definitions were not composed as complete grammatical sentences. Where this occurred, a verb or preposition was inferred for inclusion in the spreadsheet. All verb-preposition pairs presented in the spreadsheets maintain their original phrasing, except for noted exceptions, especially inferences. Wherever a word had to be inferred from the context of the definition, it has been indicated by parentheses in the spreadsheet. An effort was made to keep inferred verbs simple and unassuming in nature while still filling the function of the verb. For example, the verb "to go" implies a movement from one point to another without adding any further assumptions, such as speed or directionality - this can be seen in the SDTS definition for "Route":

- Route: A designated path through a road network.

- Predicate: (goes)THROUGH

- Other common verbs used in these instances include "to be" and "to use."

The inferring of prepositions proved to be problematic, as all prepositions have particular meanings, and many can have multiple meanings. The preposition "on" can have several different meanings dependent upon the context, as shown in these examples from SDTS:

- Airport: A facility, either on land or water, where aircraft can takeoff and land; usually consists of hardsurfaced landing strips, a control tower, hangars, and accommodations for passengers and cargo.

- Crater: Circular-shaped depression at the summit of a volcano or on the surface of the land.
- Fault: A fracture in the Earth's crust with displacement on one side of the fracture relative to the other.

In the above examples, "on" can, respectively, have the different semantic meanings "built in contact with and perhaps supported by", "within and made of", or "located at or relative to a center line."

Verbs and prepositions in the place of the predicate of the definition or implying relation to features can be of multiple types. A word can be used as an adverb, adjective, or preposition, or some other combination of types. For example, the word "beyond" can be a noun (the great beyond), preposition (beyond the lake), or an adverb (it's beyond great). Words take various grammatical forms, such as tenses or participles. Verbs sometimes appeared in pairs, such as “* * * disappears underground at $* * *$ and $* * *$ reappears at the surface ***."

Several definitions contained multiple relations and associations. One difficulty with applying definitions in terms of spatial relations was that many of these were not defined spatially, but rather by material composition or an intended purpose. Some were even defined by temporal or qualitative constraints (examples from the Geonames and SDTS datasets):

- Canal: Manmade waterway used by watercraft or for drainage, irrigation, mining, or water power (ditch).

- Overfalls: Short breaking waves occurring when a current passes over a shoal or other submarine obstruction or meets a contrary current or wind.

Recording examples and instances of fuzzy logic also was problematic. For example, where a peninsula is defined as being "nearly surrounded by" water, the tendency would be to record the spatial relation predicate as "nearly_surroundedBY" instead of "surroundedBY", because the latter does not correctly convey the intended meaning. However, the effect that the fuzzy logic term "nearly" bears upon the semantic meaning can be interpreted to have an outside and separate meaning from "surroundedBY." In the creation of a working ontology, the fuzzy logic aspect could be included from other aspects of the programming instead of coding the distinction in the Resource Description Framework (RDF) predicate-programming this in an alternate way would, in fact, be preferable to account for gradient levels.

This small-scale analysis provides an introduction to some of the challenges to be expected in the development of a formal ontology from text to RDF definitions. Ambiguous expressions for deeper semantic meanings can benefit a system designed for spatial relations data mining by reducing the number of rules of all semantic variants. Nevertheless, the further refinement of the embedded semantic meanings behind the representative forms of the words used to express them would benefit any ontology designed to approximate natural language semantics. 


\section{Results}

Words were examined in topographical context to determine a general categorization. Terms were divided between two main groups: spatial relations among topographical features, as would be used with two or more such features, and feature attributes that characterize features alone. Within these, relations were grouped as active verbs, verbs of being, and prepositions. Attributes were grouped into terms indicating location, description, or generative processes. These categories also can include inverses of terms. For example, a feature can be assigned an attribute to represent the result it generates and the morphological forces to which it is subject. Relations and attributes can combine to form complex properties.

The list of terms compiled from this study is neither conclusive nor final. No results regarding word syntax are offered. The list serves as a baseline vocabulary for development and refinement.

\section{Spatial Relations}

Most predicates extracted from the standards were verb/ preposition pairs (table 1). Active verbs (for example, words of motion) were most numerous. Prepositions often were determined to be used as spatial relations. Verb/preposition combinations can have multiple terms, such as "cast up upon." Some verb/preposition combinations could be replaced by single verbs, such as "carry out" to mean "execute." Synonyms were noted; a tension was noted between a simpler term,

Table 1. Verb/preposition pairs functioning as predicates in feature term glossaries.

\begin{tabular}{lllll}
\hline & \multicolumn{2}{l}{ Active verbs } & \multicolumn{2}{c}{ Spatial prepositions } \\
\hline access & descend & function & above & near \\
advance & direct & goes & across & of \\
approach & disappear & interrupt & along & on \\
attached & distribute & issue & alongside & out \\
backed & divide & move & around & over \\
borders & ejected & pass & at & through \\
buried & enclose & passage & below & to \\
change & entry & raise & between & toward \\
connect & exit & reappears & beyond & under \\
contact & fall & resist & by & where \\
control & fill & run & from & with \\
course & float & rush & into & within \\
cover & flow & strung & & \\
cross & follow & sunk & & \\
departure & fronted & transport & & \\
\hline
\end{tabular}

which may be more widely used, but may be more ambiguous than a specific term, as in "underground" or "subterranean."

The verb/preposition pairs are context dependent and are nuanced in meaning within the syntax and semantics of sentences. The context of some verbs created criteria for inclusion or exclusion from the study.

Active verbs also could imply locative or generative properties, such as "located," "stored," or "positioned." "Built," "caused," "constructed," or "formed" all indicate topographical processes of feature formation. Such attributes were categorized as "locator" or "generator", and are discussed in the next section.

Verbs of being include "is" and "are," and passive verbs implying affordance, relevant properties of ontologies, such as, "affords" or "capable" were not considered spatial relations (Sen, 2008). Verb/preposition pairs that indicate purpose, such as "intended for" or "intended to be," are nonspatial in nature, but could play a role as attributes. This possibility also applies to ownership, administration, or control. Passive verbs can imply part relations, such as "having," "composed," "consisting," and others. Terms that are classified as "part" relations do not include independent features, as a structure is an independent feature though it may be part of a built-up area. Part relations are indicated by a verb, such as "consist," or a term from a spatial reference system, such as "bottom."

Several verbs were events involving features that would not be considered topographical, such as "ship." In this example, verbs such as "anchored," "berthed," and "moored" were categorized as events or affordances relating to topographical features, to "port," in this example, and not categorized as predicates or spatial relations between topographical features (Gibson, 1977).

The remaining topological terms can be either verbs, such as "crosses" or adjectives, such as "adjacent to." Only two of the eight standard Open Geospatial Consortium (OGC) spatial relation terms were used in the glossaries, "within" and "contains." Many glossary terms were synonyms or close approximations to standard terms, or "fuzzy" matches. Besides serving as triple predicates, topological relations may be leveraged for the logical consistency of data and spatial analysis. Once they are tied to the topology of geospatial data involving geometric feature types, such as "area" or "point," predicates matching geometry types to feature types may support rules controlling the consistency of relations between features. For example, logical consistency rules involving topological predicates would prevent an error such as "crosses" when two polygons actually "overlap."

\section{Feature Attributes}

Attributes are nonspatial terms or spatial terms lacking relative relations to other features that characterize triple resources. Most adjectives present in feature type definitions indicated attributes, such as "known," "away," "out," and "parallel." Three general types of attributes were 
identified from glossaries, called "Locator," "Descriptor," and "Generator."

Feature attributes categorized as Locator are words with express location descriptions. In this group included are, "underground" and "positioned." Many prepositions, such as "where" or "at," indicate location.

Descriptors are attribute terms that are humanly-perceived. Descriptors usually take the form of adjectives, but are not abstract, such as "away" or "out." Terms characterized as descriptors include: "curve," "depression," "slopes," "broken," or "visible."

Terms of feature generation, called Generator attributes, include active verbs representing causes or processes that directly relate to the formation of the feature, not just having an affect on the feature. This set of terms applies to a wide range of human activities on the landscape, such as "cultivated" or "developed." Other terms are more generic, such as "adapted," "maintained," "created," or "determined."

\section{Conclusions}

Natural language spatial relations used in topographic science are complex phrases involving a range of properties. In addition to Geographic Information Systems approaches involving topology and geometric values of distance and direction, linguistic terms easily can communicate meaning to a diverse public, but they are complex and difficult to systematize in geospatial semantic web applications. Some relations embedded in the glossary are common terms with the Open Geospatial Consortium Simple Feature model operators, but can be expanded from binary topology between features to include resource systems and region fields. For example, the transitive property applies to terms such as "within" so that if $A$ is within $B$, and $B$ is within $C$, then $A$ is within $C$.

Though the analysis focused primarily on verb/preposition pairs, other types of relations found in the complex phrases include properties indicating state of being (such as, "composed of"), location (such as, "subterranean") and feature parts (such as, "entrance"). Topographic terms indicating a part of a feature were sometimes defined in terms of the motion or event it allows. For example, an entrance "**** affords entry to $* * *$ " Other types of properties that were semantically related to spatial relations, especially in the physical or material world, included terms of description (such as, "high" or "near"), generation of physical processes (such as, "naturally formed"), and motion (such as, "approaches"). The identification of these properties aids the representation of the complexity of phrases, which can be expressed as graphs or as a list of triples using common identifiers for resources, identifiers, or values.

The set of verb/preposition pairs found in this study function as predicates, together with topographic feature attributes, and compose a corpus of work that offers promise for user/ technology interface facilitation. Such interfaces may involve geographic information extraction, topographic feature identification, science process modeling, and visualization.

\section{References Cited}

Beckett, D., 2004, RDF/XML Syntax Specification (Revised), W3C, accessed July 19, 2011, at http://www.w3.org/TR/ REC-rdf-syntax/.

Berners-Lee, T., Hendler, J., and Lassila, O., 2001, The semantic web: The Scientific American, v. 284, no. 5, p. 34-43.

Egenhofer, M.J., 2002, Toward the semantic geospatial web in Proceedings of GIS 2002, November 8-9, 2002, McLean, Virginia, USA.

Egenhofer, M.J., and Franzosa, R., 1991, Point-set topological spatial relations: International Journal of Geographical Information Systems, v. 5, p. 161-174.

Egenhofer, M., and Herring, J., 1991, Categorizing binary topological relationships between regions, lines, and points in geographic databases in M. Egenhofer, J.Herring, T. Smith, and K. Park, eds., A framework for the definitions of topological relationships and an algebraic approach to spatial reasoning within this framework: NCGIA Technical Report 91-7, National Center for Geographic Information and Analysis, Santa Barbara Cailf.

Gibson, J., 1977, The theory of affordances in R. Shaw and J. Bransford, eds., Perceiving, acting, and knowing - toward an ecological psychology, Lawrence Erlbaum Associates, p. $67-82$.

Herskovits, A., 1986, Language and spatial cognition - an interdisciplinary study of the prepositions in English: Cambridge University Press, Cambridge, 208 p.

Hirtle, S.C., and Frank, A.U., eds., 1997, Spatial information theory - a theoretical basis for GIS: Berlin, Springer-Verlag, $492 \mathrm{p}$.

International Organization for Standardization, 2003, Geographic information-spatial schema: ISO 19107:2003.

Kokla, M., and Kavouras, M., 2005, Semantic information in geo-ontologies - extraction, comparison, and reconciliation: Journal on Data Semantics, v 3, p 125-142.

Levinson, S.C., 2003, Space in language and cognition: Cambridge, Cambridge University Press.

Mizen, H., Dolbear, C., and Hart, G., 2005, Ontology ontogeny-understanding how an Ontology is created and developed in First International Conference on GeoSpatial Semantics, GeoS 2005, November 29-30, 2005, Mexico City, p. 15-29. 
Orth, D.J. and Payne, R.L., 1997, Principles, policies, and procedures - domestic geographic names: U.S. Board on Geographic Names, Reston, Virginia, accessed March 30, 2011, at http://geonames.usgs.gov/docs/pro_pol_pro.pdf.

Perry, M. and Herring, J., 2010, GeoSPARQL-A geographic query language for RDF data: Open Geospatial Consortium Inc., Reference number OGC 09-157r3.

Sen, S., 2008, Use of affordances in geospatial ontologieslecture notes in computer science: v. 4,760, p. 122-139.

Shariff, A.R., Egenhofer, M.J., and Mark, D.M., 1998, Natural-language spatial relations between linear and areal objects - the topology and metric of English-language terms: International Journal of Geographic Information Science, v. 12, no. 3, p. 215-245.

Talmy, L., 1983, How language structures space in Pick, H.L., and Acredolo, L.P., eds., Spatial orientation - theory, research and application: Plenum Press, New York, p. 225-282.

U.S. Board on Geographic Names, 2010, Geographic Names Information System, accessed March 25, 2010, at http://geonames.usgs.gov/domestic/index.html.

U.S. Geological Survey, 2010, National Geospatial Program Standards, accessed March 23, 2010, at http://nationalmap. gov/gio/standards/.

U.S. Geological Survey, 1984, Standards for 1:24,000- and 1:25,000-scale quadrangle maps; part 5 publication symbols: Department of the Interior, U.S. Geological Survey, Washington D.C.

World Wide Web Consortium (W3C), 2010, Semantic Web, World Wide Web Consortium (W3C), accessed July 19, 2011, at http://www.w3.org/standards/semanticweb/.

World Wide Web Consortium (W3C), 2008, SPARQL Query Language for RDF, accessed July 14, 2010, at $h t t p: / / w w w$. w3.org/TR/rdf-sparql-query/.

Watt, R.J.C., 2009a, Concordance 3.3, accessed July 19, 2011, at $h t t p: / / w w w . c o n c o r d a n c e s o f t w a r e . c o . u k /$.

Watt, R.J.C., 2009b, Concordance 3.3 Help ContentsLemmatisation, accessed July 19, 2011, at $h t t p: / / w w w$. concordancesoftware.co.uk/manual/hs2330.htm. 
Appendixes 
Appendix 1. Predicate terms in Digital Line Graph (DLG) standard feature definitions.

[The data analyzed in this table is based on the DLG standard. The text from the original documents was changed as little as possible and only for research purposes. As a result, the glossary definitions may appear to be breaking rules of grammar, but were arranged to help clarify semantic meanings. Feature type terms are listed in alphabetical order. Verbs appear in lowercase and prepositions appear in uppercase fonts. Inferred terms are presented within parentheses. ,-- no data]

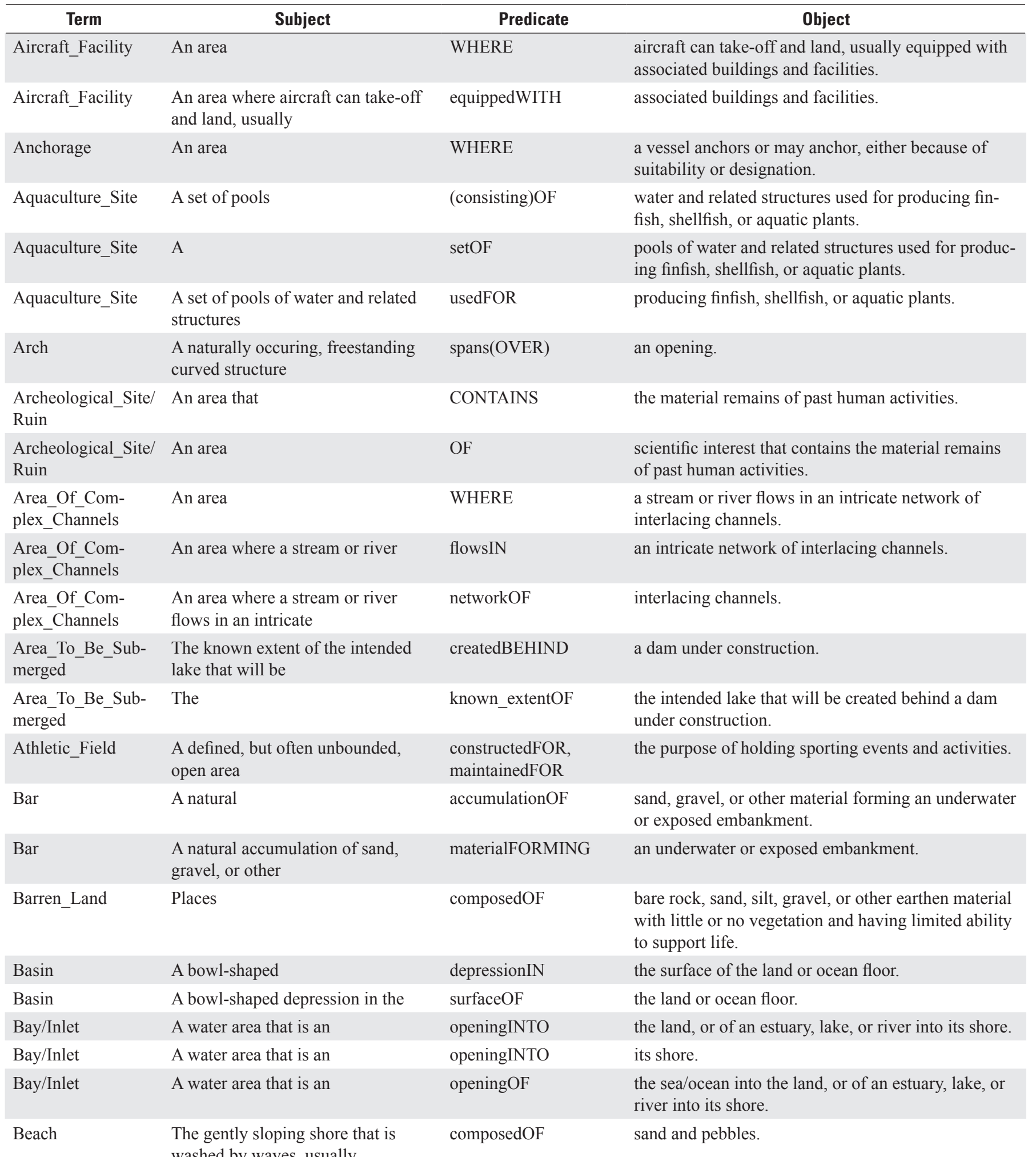

washed by waves, usually 


\section{Appendix 1. Predicate terms in Digital Line Graph (DLG) standard feature definitions.—Continued}

[The data analyzed in this table is based on the DLG standard. The text from the original documents was changed as little as possible and only for research purposes. As a result, the glossary definitions may appear to be breaking rules of grammar, but were arranged to help clarify semantic meanings. Feature type terms are listed in alphabetical order. Verbs appear in lowercase and prepositions appear in uppercase fonts. Inferred terms are presented within parentheses. ,-- no data]

\begin{tabular}{|c|c|c|c|}
\hline Term & Subject & Predicate & Object \\
\hline Beach & $\begin{array}{l}\text { The gently sloping shore that is } \\
\text { washed by waves, usually }\end{array}$ & is_washedBY & waves, usually composed of sand and pebbles. \\
\hline Bend & A & curveIN & the course of a stream or the land within the curve. \\
\hline Boardwalk & A promenade, usually & constructedOF & planks. \\
\hline Boundary_Line & $\begin{array}{l}\text { The limiting line of jurisdictional } \\
\text { authority }\end{array}$ & usedFOR & various levels of government. \\
\hline Boundary_Point & An identified & $\begin{array}{l}\text { locationON, } \\
\text { locationNEAR }\end{array}$ & a current boundary or former boundary. \\
\hline Bridge & A structure & $\begin{array}{l}\text { spanningOVER, pro- } \\
\text { viding_passageOVER }\end{array}$ & a waterway, railroad, or other obstacle. \\
\hline Built-Up_Area & An area & $\mathrm{OF}$ & $\begin{array}{l}\text { intensive use, with much of the land covered by } \\
\text { structures. }\end{array}$ \\
\hline Built-Up_Area & $\begin{array}{l}\text { An area of intensive use, with much } \\
\text { of the land }\end{array}$ & coveredBY & structures. \\
\hline Cable/Pipeline_Site & An area where cables or pipelines & are_locatedUNDER & water. \\
\hline Cable/Pipeline_Site & An area & WHERE & cables or pipelines are located under water. \\
\hline Cableway & $\begin{array}{l}\text { A conveyor system in which carrier } \\
\text { units }\end{array}$ & are_suspendedFROM & wire cables strung between supports. \\
\hline Cableway & $\begin{array}{l}\text { A conveyor system in which car- } \\
\text { rier units are suspended from wire } \\
\text { cables }\end{array}$ & strungBETWEEN & supports. \\
\hline Cape & A projection of land & extendingINTO & $\begin{array}{l}\text { a body of water that prominently marks a change in } \\
\text { or interrupts the coastal trend of that water body. }\end{array}$ \\
\hline Cape & $\begin{array}{l}\text { A projection of land extending into } \\
\text { a body of water that prominently } \\
\text { marks a change in or interrupts the } \\
\text { coastal }\end{array}$ & trendOF & that water body. \\
\hline Cave_Entrance & A passage that affords & entryTO & $\begin{array}{l}\text { a naturally formed subterranean open area or } \\
\text { chamber. }\end{array}$ \\
\hline Cemetery & A burial ground. & -- & -- \\
\hline Chimney & $\begin{array}{l}\text { A structure containing a passage or } \\
\text { flue for }\end{array}$ & discharging $(\mathrm{OF})$ & combustion smoke and gases. \\
\hline
\end{tabular}




\section{Appendix 1. Predicate terms in Digital Line Graph (DLG) standard feature definitions._- Continued}

[The data analyzed in this table is based on the DLG standard. The text from the original documents was changed as little as possible and only for research purposes. As a result, the glossary definitions may appear to be breaking rules of grammar, but were arranged to help clarify semantic meanings. Feature type terms are listed in alphabetical order. Verbs appear in lowercase and prepositions appear in uppercase fonts. Inferred terms are presented within parentheses. ,-- no data]

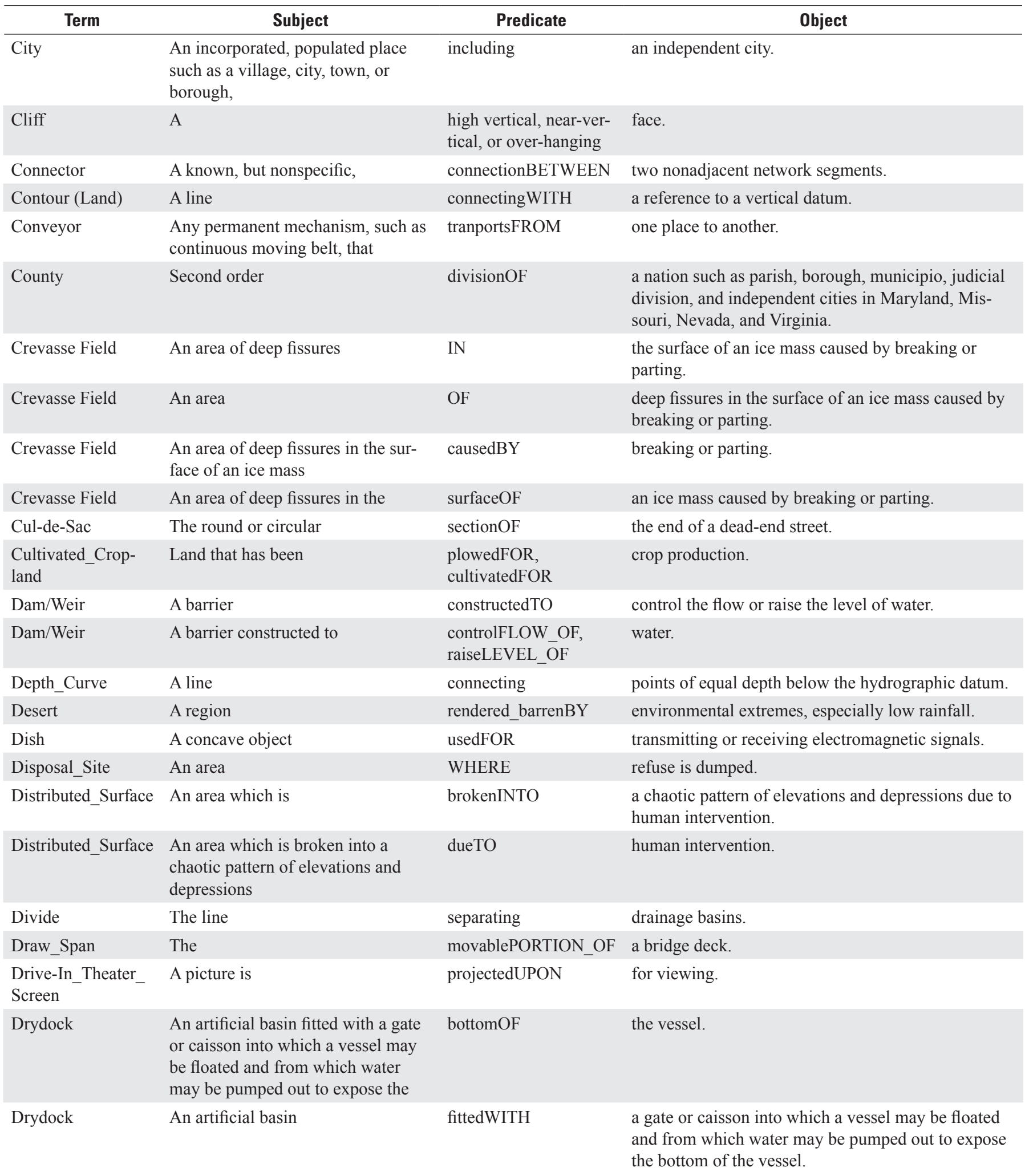




\section{Appendix 1. Predicate terms in Digital Line Graph (DLG) standard feature definitions._-Continued}

[The data analyzed in this table is based on the DLG standard. The text from the original documents was changed as little as possible and only for research purposes. As a result, the glossary definitions may appear to be breaking rules of grammar, but were arranged to help clarify semantic meanings. Feature type terms are listed in alphabetical order. Verbs appear in lowercase and prepositions appear in uppercase fonts. Inferred terms are presented within parentheses. ,-- no data]

\begin{tabular}{|c|c|c|c|}
\hline Term & Subject & Predicate & Object \\
\hline Drydock & A vessel may be & floatedINTO. & -- \\
\hline Drydock & Water may be & pumped_outFROM & to expose the bottom of the vessel. \\
\hline Dunes & Hills or ridges & (composed)OF & sand piled up by the wind. \\
\hline Dunes & Hills or ridges of sand & piled_upBY & the wind. \\
\hline Embankment & A & $\begin{array}{l}\text { raisedLINEAR_- } \\
\text { MOUND_OF }\end{array}$ & earth, gravel, or similar material. \\
\hline Estuary & $\begin{array}{l}\text { The lower end of a river, or a } \\
\text { semienclosed coastal body of water } \\
\text { with access to the open ocean, } \\
\text { which is affected by the tides and }\end{array}$ & (is)WHERE & fresh and salt water mix. \\
\hline Estuary & $\begin{array}{l}\text { The lower end of a river, or a } \\
\text { semienclosed coastal body of water } \\
\text { with }\end{array}$ & accessTO & $\begin{array}{l}\text { the open ocean, which is affected by the tides and } \\
\text { where fresh and salt water mix. }\end{array}$ \\
\hline Estuary & $\begin{array}{l}\text { The lower end of a river, or a } \\
\text { semienclosed coastal body }\end{array}$ & composedOF & $\begin{array}{l}\text { water with access to the open ocean, which is } \\
\text { affected by the tides and where fresh and salt water } \\
\text { mix. }\end{array}$ \\
\hline Estuary & The lower & endOF & $\begin{array}{l}\text { a river, or a semienclosed coastal body of water with } \\
\text { access to the open ocean, which is affected by the } \\
\text { tides and where fresh and salt water mix. }\end{array}$ \\
\hline Estuary & $\begin{array}{l}\text { The lower end of a river, or a } \\
\text { semienclosed coastal body of water } \\
\text { with access to the open ocean, } \\
\text { which }\end{array}$ & is_affectedBY & the tides and where fresh and salt water mix. \\
\hline Exhibition_Ground & $\begin{array}{l}\text { A public area where outdoor fairs, } \\
\text { circuses, and other events are held, } \\
\text { which also contains permanent } \\
\text { structures }\end{array}$ & (used)FOR & $\begin{array}{l}\text { the display of livestock, machinery, agricultural } \\
\text { produce, etc. }\end{array}$ \\
\hline Exhibition_Ground & $\begin{array}{l}\text { A public area where outdoor fairs, } \\
\text { circuses, and other events are held, } \\
\text { which also }\end{array}$ & CONTAINS & $\begin{array}{l}\text { permanent structures for the display of livestock, } \\
\text { machinery, agricultural produce, etc. }\end{array}$ \\
\hline Exhibition_Ground & A public area & WHERE & $\begin{array}{l}\text { outdoor fairs, circuses, and other events are held, } \\
\text { which also contains permanent structures for the } \\
\text { display of livestock, machinery, agricultural produce, } \\
\text { etc. }\end{array}$ \\
\hline Fence_Line & An identifiable fence or field line & visibleON & an aerial photograph. \\
\hline Filtration_Plant & A group & composedOF & $\begin{array}{l}\text { structures functioning as a unit used for the purifica- } \\
\text { tion and distribution of a water supply. }\end{array}$ \\
\hline Filtration_Plant & A group of structures & functioningAS & $\begin{array}{l}\text { a unit used for the purification and distribution of a } \\
\text { water supply. }\end{array}$ \\
\hline Filtration_Plant & $\begin{array}{l}\text { A group of structures functioning as } \\
\text { a unit used for the }\end{array}$ & $\begin{array}{l}\text { purificationOF, } \\
\text { distributionOF }\end{array}$ & a water supply. \\
\hline Filtration_Plant & $\begin{array}{l}\text { A group of structures functioning } \\
\text { as a unit }\end{array}$ & usedFoR & the purification and distribution of a water supply. \\
\hline Fish_Ladder & $\begin{array}{l}\text { A facility consisting of a series of } \\
\text { small pools, each one slightly higher } \\
\text { than the preceding, }\end{array}$ & builtAROUND & $\begin{array}{l}\text { an obstruction to enable fish to make their way } \\
\text { upstream. }\end{array}$ \\
\hline
\end{tabular}




\section{An Analysis of Spatial Relation Predicates in U.S. Geological Survey Feature Definitions}

\section{Appendix 1. Predicate terms in Digital Line Graph (DLG) standard feature definitions.—Continued}

[The data analyzed in this table is based on the DLG standard. The text from the original documents was changed as little as possible and only for research purposes. As a result, the glossary definitions may appear to be breaking rules of grammar, but were arranged to help clarify semantic meanings. Feature type terms are listed in alphabetical order. Verbs appear in lowercase and prepositions appear in uppercase fonts. Inferred terms are presented within parentheses. ,-- no data]

\begin{tabular}{|c|c|c|c|}
\hline Term & Subject & Predicate & Object \\
\hline Fish_Ladder & A facility & consistingOF & $\begin{array}{l}\text { a series of small pools, each one slightly higher than } \\
\text { the preceding, built around an obstruction to enable } \\
\text { fish to make their way upstream. }\end{array}$ \\
\hline Fish_Ladder & $\begin{array}{l}\text { A facility consisting of a series of } \\
\text { small pools, each one slightly higher } \\
\text { than the preceding, built around an }\end{array}$ & obstructionTO & enable fish to make their way upstream. \\
\hline Fish_Ladder & A facility consisting of a & seriesOF & $\begin{array}{l}\text { small pools, each one slightly higher than the preced- } \\
\text { ing, built around an obstruction to enable fish to } \\
\text { make their way upstream. }\end{array}$ \\
\hline Flume & An open, inclined, artificial channel & constructedOF & wood, metal, or concrete; generally elevated. \\
\hline Ford & A location in a body & composedOF & $\begin{array}{l}\text { water for a road or trail crossing where the physi- } \\
\text { cal characteristics of the bottom, water depth, and } \\
\text { approaches permit passage without a bridge or ferry. }\end{array}$ \\
\hline Ford & $\begin{array}{l}\text { A location in a body of water for a } \\
\text { road or trail }\end{array}$ & crossingWHERE & $\begin{array}{l}\text { the physical characteristics of the bottom, water } \\
\text { depth, and approaches permit passage without a } \\
\text { bridge or ferry. }\end{array}$ \\
\hline Ford & A & locationIN & $\begin{array}{l}\text { a body of water for a road or trail crossing where the } \\
\text { physical characteristics of the bottom, water depth, } \\
\text { and approaches permit passage without a bridge or } \\
\text { ferry. }\end{array}$ \\
\hline Ford & A location in a body of water & usedFOR & $\begin{array}{l}\text { a road or trail crossing where the physical charac- } \\
\text { teristics of the bottom, water depth, and approaches } \\
\text { permit passage without a bridge or ferry. }\end{array}$ \\
\hline Foreshore & The part of a seashore & (is)BETWEEN & high-water and low-water marks. \\
\hline Foreshore & The & part of & a seashore between high-water and low-water marks. \\
\hline Fracture & A deformation in the Earth's crust & causedBY & a loss of cohesion. \\
\hline Fracture & A & deformationIN & the Earth's crust caused by a loss of cohesion. \\
\hline Fumarole & steam and gases are & emmittedFROM & a hole in the earth's crust. \\
\hline Gaging_Station & A structure & usedTO & measure the characteristics of a hydrographic feature. \\
\hline Gap & A & $\begin{array}{l}\text { low_pointBETWEEN, } \\
\text { openingBETWEEN }\end{array}$ & mounts or in a ridge. \\
\hline Gap & A & $\begin{array}{l}\text { low_pointIN, } \\
\text { openingIN }\end{array}$ & a ridge. \\
\hline Gate & A structure that may be & $\begin{array}{l}\text { swungTO, drawnTO, } \\
\text { loweredTO }\end{array}$ & block an entrance or passageway. \\
\hline Geyser & A natural fountain that intermittently & ejectsFROM & a hole in the Earth's crust. \\
\hline Geyser & A natural fountain that intermittently & ejectsINTO & the air from a hole in the Earth's crust. \\
\hline Hazard_Zone & An area & identifiedAS & a danger to maritime navigation. \\
\hline Helipad & A structure & usedFOR & the landing and take-off of helicopters. \\
\hline \multicolumn{4}{|l|}{$\begin{array}{l}\text { Historical_Monu- } \\
\text { ment }\end{array}$} \\
\hline Holding_Pen & Livestock are temporarily & keptIN & an enclosed area. \\
\hline Ice_Mass & A field of ice, & formedIN & regions of perennial frost. \\
\hline
\end{tabular}




\section{Appendix 1. Predicate terms in Digital Line Graph (DLG) standard feature definitions.—Continued}

[The data analyzed in this table is based on the DLG standard. The text from the original documents was changed as little as possible and only for research purposes. As a result, the glossary definitions may appear to be breaking rules of grammar, but were arranged to help clarify semantic meanings. Feature type terms are listed in alphabetical order. Verbs appear in lowercase and prepositions appear in uppercase fonts. Inferred terms are presented within parentheses. -- , no data]

\begin{tabular}{|c|c|c|c|}
\hline Term & Subject & Predicate & Object \\
\hline Iceberg & $\begin{array}{l}\text { Large mass of floating or stranded } \\
\text { ice of greatly varying shape, more } \\
\text { than } 5 \text { meters above sea level, which } \\
\text { has }\end{array}$ & brokenAWAY & from a glacier. \\
\hline Iceberg_Tongue & $\begin{array}{l}\text { A major accumulation of icebergs } \\
\text { projecting from the coast, }\end{array}$ & held_in_placeBY & by grounding and joined together by fast ice. \\
\hline Iceberg_Tongue & $\begin{array}{l}\text { A major accumulation of icebergs } \\
\text { projecting from the coast, held in } \\
\text { place by grounding and }\end{array}$ & joined_togetherBY & fast ice. \\
\hline Iceberg_Tongue & A major accumulation of icebergs & projectingFROM & $\begin{array}{l}\text { the coast, held in place by grounding and joined } \\
\text { together by fast ice. }\end{array}$ \\
\hline Incline/Flow & A feature & characterizedBY & $\begin{array}{l}\text { a sloping surface or a formation resulting from move- } \\
\text { ment down a sloping surface. }\end{array}$ \\
\hline Incline/Flow & $\begin{array}{l}\text { A feature characterized by a sloping } \\
\text { surface or a formation }\end{array}$ & resultingFROM & movement down a sloping surface. \\
\hline Institutional_Site & $\begin{array}{l}\text { A group of buildings or associated } \\
\text { structures, }\end{array}$ & functioningAS & $\begin{array}{l}\text { a unit, used predominantly for educational, correc- } \\
\text { tional, governmental, medical, or religious purposes. }\end{array}$ \\
\hline Interchange & An area & designatedTO & $\begin{array}{l}\text { provide traffic access between roadways of differing } \\
\text { levels. }\end{array}$ \\
\hline Interchange & An area designated to & $\begin{array}{l}\text { provide_accessBE- } \\
\text { TWEEN }\end{array}$ & roadways of differing levels. \\
\hline Inundation_Area & An area of land & subjectTO & flooding. \\
\hline Island & An area of dry or relatively dry land & surroundedBY & water or low wetland. \\
\hline Isthmus & A narrow strip of land, & borderedBY & water, connecting two larger land areas. \\
\hline Isthmus & A narrow strip of land, & borderedON & both sides by water, connecting two larger land areas. \\
\hline Isthmus & $\begin{array}{l}\text { A narrow strip of land, bordered on } \\
\text { both sides by water, }\end{array}$ & connecting & two larger land areas. \\
\hline Junction & $\begin{array}{l}\text { An intersection or confluence of two } \\
\text { or more adjacent network segments, } \\
\text { or a terminus of a single network } \\
\text { segment. Network segments }\end{array}$ & $\operatorname{areIN}$ & $\begin{array}{l}\text { a roadway network or drainage network that have } \\
\text { direction of flow or carry traffic. }\end{array}$ \\
\hline Junction & $\begin{array}{l}\text { An intersection or confluence of two } \\
\text { or more adjacent network segments, } \\
\text { or a terminus of a single network } \\
\text { segment. Network segments are } \\
\text { those links in a roadway network or } \\
\text { drainage network that }\end{array}$ & have_directionOF & flow or carry traffic. \\
\hline Junction & An & $\begin{array}{l}\text { intersectionOF, } \\
\text { confluenceOF }\end{array}$ & $\begin{array}{l}\text { two or more adjacent network segments, or a termi- } \\
\text { nus of a single network segment. Network segments } \\
\text { are those links in a roadway network or drainage } \\
\text { network that have direction of flow or carry traffic. }\end{array}$ \\
\hline Junction & $\begin{array}{l}\text { An intersection or confluence of two } \\
\text { or more adjacent network segments, } \\
\text { or a }\end{array}$ & terminusOF & $\begin{array}{l}\text { a single network segment. Network segments are } \\
\text { those links in a roadway network or drainage network } \\
\text { that have direction of flow or carry traffic. }\end{array}$ \\
\hline Kiln & Any of various ovens & (used)FOR & hardening, burning, or drying substances. \\
\hline Lake/Pond & $\begin{array}{l}\text { A standing body of water with a } \\
\text { predominantly natural shoreline }\end{array}$ & surroundedBY & land. \\
\hline
\end{tabular}




\section{Appendix 1. Predicate terms in Digital Line Graph (DLG) standard feature definitions._- Continued}

[The data analyzed in this table is based on the DLG standard. The text from the original documents was changed as little as possible and only for research purposes. As a result, the glossary definitions may appear to be breaking rules of grammar, but were arranged to help clarify semantic meanings. Feature type terms are listed in alphabetical order. Verbs appear in lowercase and prepositions appear in uppercase fonts. Inferred terms are presented within parentheses. ,-- no data]

\begin{tabular}{|c|c|c|c|}
\hline Term & Subject & Predicate & Object \\
\hline Land_Grant & $\begin{array}{l}\text { An area of land to which title was } \\
\text { conferred by a predecessor govern- } \\
\text { ment and confirmed by the U.S. } \\
\text { Government after the territory in } \\
\text { which it is situated was }\end{array}$ & acquiredBY & the United States. \\
\hline Land_Grant & An area of land to which title was & conferredBY & $\begin{array}{l}\text { a predecessor government and confirmed by the U.S. } \\
\text { Government after the territory in which it is situated } \\
\text { was acquired by the United States. }\end{array}$ \\
\hline Land_Grant & $\begin{array}{l}\text { An area of land to which title was } \\
\text { conferred by a predecessor govern- } \\
\text { ment and }\end{array}$ & confirmedBY & $\begin{array}{l}\text { the U.S. Government after the territory in which it is } \\
\text { situated was acquired by the United States. }\end{array}$ \\
\hline Lane & A & prescribed_courseFOR & ships, boats, or seaplanes. \\
\hline Launch_Facility & An area & (is)WHERE & $\begin{array}{l}\text { rockets or missiles may be housed and from which } \\
\text { they are launched, usually equipped with associated } \\
\text { buildings and facilities. }\end{array}$ \\
\hline Launch_Facility & $\begin{array}{l}\text { An area where rockets or missiles } \\
\text { may be housed and }\end{array}$ & launchedFROM & $\begin{array}{l}\text { usually equipped with associated buildings and } \\
\text { facilities. }\end{array}$ \\
\hline Launch_Pad & a rocket or missile is & launchedFROM & a structure. \\
\hline Launching_Ramp & A partially submerged hard surface & (is) $\mathrm{ON}$ & $\begin{array}{l}\text { on a shoreline for launching or retrieving vessels or } \\
\text { aircraft. }\end{array}$ \\
\hline Launching_Ramp & $\begin{array}{l}\text { A partially submerged hard surface } \\
\text { on a shoreline }\end{array}$ & (used)FOR & launching or retrieving vessels or aircraft. \\
\hline Locale & $\begin{array}{l}\text { A named place not otherwise } \\
\text { categorized. }\end{array}$ & -- & -- \\
\hline Marina & $\begin{array}{l}\text { A harbor facility for recreational } \\
\text { craft }\end{array}$ & (is)WHERE & supplies, repairs, and various services are available. \\
\hline Marina & A harbor facility & (used)FOR & $\begin{array}{l}\text { recreational craft where supplies, repairs, and various } \\
\text { services are available. }\end{array}$ \\
\hline Mile_Marker & A point & (is) $\mathrm{ON}$ & $\begin{array}{l}\text { a feature indicating the distance, in miles, measured } \\
\text { along the course or path of the feature, from an estab- } \\
\text { lished origin point on the feature. }\end{array}$ \\
\hline Mile_Marker & $\begin{array}{l}\text { A point on a feature indicating the } \\
\text { distance, in miles, measured along } \\
\text { the course or path of the feature, } \\
\text { from an established origin point }\end{array}$ & (is) $\mathrm{ON}$ & the feature. \\
\hline Mile_Marker & $\begin{array}{l}\text { A point on a feature indicating the } \\
\text { distance, in miles, }\end{array}$ & measuredALONG & $\begin{array}{l}\text { the course or path of the feature, from an established } \\
\text { origin point on the feature. }\end{array}$ \\
\hline
\end{tabular}




\section{Appendix 1. Predicate terms in Digital Line Graph (DLG) standard feature definitions.—Continued}

[The data analyzed in this table is based on the DLG standard. The text from the original documents was changed as little as possible and only for research purposes. As a result, the glossary definitions may appear to be breaking rules of grammar, but were arranged to help clarify semantic meanings. Feature type terms are listed in alphabetical order. Verbs appear in lowercase and prepositions appear in uppercase fonts. Inferred terms are presented within parentheses. ,-- no data]

\begin{tabular}{|c|c|c|c|}
\hline Term & Subject & Predicate & Object \\
\hline Mile_Marker & $\begin{array}{l}\text { A point on a feature indicating the } \\
\text { distance, in miles, }\end{array}$ & measuredFROM & an established origin point on the feature. \\
\hline Mine & An excavation in the earth & $\begin{array}{l}\text { (is)FOR_THE_PUR- } \\
\text { POSE_OF }\end{array}$ & extracting earth materials. \\
\hline Mine & An excavation & (is) IN & the earth for the purpose of extracting earth materials \\
\hline Mine_Entrance & Passage that & affords_entryTO & an underground mine. \\
\hline $\begin{array}{l}\text { Minor_Civil_Divi- } \\
\text { sion }\end{array}$ & Third order & divisionOF & $\begin{array}{l}\text { a nation such as township, town, district, precinct, or } \\
\text { barrio. }\end{array}$ \\
\hline Mobile_Home_Park & An area & maintainedFOR & the parking of inhabited mobile homes. \\
\hline Mobile_Home_Park & An area maintained for the & parkingOF & inhabited mobile homes. \\
\hline Monorail & A vehicle or train of cars & travelsON & a single rail. \\
\hline Moraine & An & accumulationOF & earth and stones carried and deposited by a glacier. \\
\hline Moraine & An accumulation of earth and stones & $\begin{array}{l}\text { carriedBY, } \\
\text { depositedBY }\end{array}$ & a glacier. \\
\hline Mount & A landmass that & projectsABOVE & its surroundings. \\
\hline Mud_Pot & gas or vapors & issueFROM & a pool of mud. \\
\hline Nation & An area & under_jurisdictionOF & a sovereign government. \\
\hline Nonearthen_Shore & $\begin{array}{l}\text { A structure built of stone, brick, } \\
\text { concrete, or other building materi- } \\
\text { als that }\end{array}$ & borders & a body of water. \\
\hline Nonearthen_Shore & A structure & builtOF & $\begin{array}{l}\text { stone, brick, concrete, or other building materials that } \\
\text { borders a body of water. }\end{array}$ \\
\hline Offshore_Platform & A raised structure located in a sea, & equippedFOR & $\begin{array}{l}\text { the extraction, loading or unloading of petroleum } \\
\text { products. }\end{array}$ \\
\hline Offshore_Platform & $\begin{array}{l}\text { A raised structure located in a sea, } \\
\text { equipped for the }\end{array}$ & $\begin{array}{l}\text { extractionOF, loadin- } \\
\text { gOF, unloadingOF }\end{array}$ & petroleum products. \\
\hline Offshore_Platform & A raised structure & locatedIN & $\begin{array}{l}\text { a sea, equipped for the extraction, loading or unload- } \\
\text { ing of petroleum products. }\end{array}$ \\
\hline Outdoor_Theater & $\begin{array}{l}\text { An outdoor area consisting of a } \\
\text { stage or other focal point, and an } \\
\text { area }\end{array}$ & (is)WHERE & $\begin{array}{l}\text { the audience can be seated to view the performance } \\
\text { or event. }\end{array}$ \\
\hline Outdoor_Theater & An outdoor area & consistingOF & $\begin{array}{l}\text { a stage or other focal point, and an area where the } \\
\text { audience can be seated to view the performance or } \\
\text { event. }\end{array}$ \\
\hline Park & A place or area & developedFOR & public use or recreation. \\
\hline $\begin{array}{l}\text { Pier/Breakwater/ } \\
\text { Jetty }\end{array}$ & Structure & extendingFROM & $\begin{array}{l}\text { the shore or positioned offshore for protection, berth- } \\
\text { ing vessels, or recreation. }\end{array}$ \\
\hline $\begin{array}{l}\text { Pier/Breakwater/ } \\
\text { Jetty }\end{array}$ & Structure & extendingIN & $\begin{array}{l}\text { the longest dimension from the shore or posi- } \\
\text { tioned offshore for protection, berthing vessels, or } \\
\text { recreation. }\end{array}$ \\
\hline $\begin{array}{l}\text { Pier/Breakwater/ } \\
\text { Jetty }\end{array}$ & $\begin{array}{l}\text { Structure extending in the longest } \\
\text { dimension from the shore or }\end{array}$ & positionedFOR & protection, berthing vessels, or recreation. \\
\hline Pinnacle & A & $\begin{array}{l}\text { vertical often } \\
\text { spire-shaped }\end{array}$ & natural rock formation. \\
\hline
\end{tabular}




\section{Appendix 1. Predicate terms in Digital Line Graph (DLG) standard feature definitions._- Continued}

[The data analyzed in this table is based on the DLG standard. The text from the original documents was changed as little as possible and only for research purposes. As a result, the glossary definitions may appear to be breaking rules of grammar, but were arranged to help clarify semantic meanings. Feature type terms are listed in alphabetical order. Verbs appear in lowercase and prepositions appear in uppercase fonts. Inferred terms are presented within parentheses. ,-- no data]

\begin{tabular}{|c|c|c|c|}
\hline Term & Subject & Predicate & Object \\
\hline Pipeline & $\begin{array}{l}\text { A closed conduit, with pumps, } \\
\text { valves and control devices, }\end{array}$ & (used)FOR & conveying fluids, gases, or finely divided solids. \\
\hline $\begin{array}{l}\text { Pipeline_Regula- } \\
\text { tion_Station }\end{array}$ & An ancillary facility that & controls_the_flowOF & fluids or gasses along a pipeline route. \\
\hline Playa & The flat area & (is) AT & $\begin{array}{l}\text { the lowest part of an undrained desert basin, gener- } \\
\text { ally devoid of vegetation. }\end{array}$ \\
\hline Playa & $\begin{array}{l}\text { The flat area at the lowest part of an } \\
\text { undrained desert basin, generally }\end{array}$ & devoidOF & vegetation. \\
\hline Populated_Place & A place or area & (is)WITH & $\begin{array}{l}\text { clustered or scattered buildings and a permanent } \\
\text { human population. }\end{array}$ \\
\hline Post & $\begin{array}{l}\text { An upright piece of timber or other } \\
\text { material, }\end{array}$ & (is) IN, adjacentTO & $\begin{array}{l}\text { a body of water, used for mooring ships or supporting } \\
\text { other structures. }\end{array}$ \\
\hline Post & $\begin{array}{l}\text { An upright piece of timber or other } \\
\text { material, in or adjacent to a body of } \\
\text { water }\end{array}$ & usedFOR & mooring ships or supporting other structures. \\
\hline Power_Site & A group of associated structures, & functioningAS & a unit, used for generating electricity. \\
\hline Power_Site & $\begin{array}{l}\text { A group of associated structures, } \\
\text { functioning as a unit, }\end{array}$ & usedFOR & generating electricity. \\
\hline Principal_Meridian & $\begin{array}{l}\text { The line extending north and south, } \\
\text { intended to follow along a true } \\
\text { meridian, from the initial point of a } \\
\text { Rectangular Survey. Ranges are }\end{array}$ & $\begin{array}{l}\text { referencedEAST_OF, } \\
\text { referencedWEST_OF }\end{array}$ & the principal meridian. \\
\hline Prospect & A marked location & (is)WHERE & $\begin{array}{l}\text { mineral exploration has occurred, but no mine has } \\
\text { been developed. }\end{array}$ \\
\hline Proving_Ground & An area & set_asideFOR & performance testing. \\
\hline $\begin{array}{l}\text { Public_Land_Sur- } \\
\text { vey_System_Area }\end{array}$ & $\begin{array}{l}\text { An area of land which is subdivided } \\
\text { by the Public Land Survey System } \\
\text { (PLSS), and was originally }\end{array}$ & createdON & $\begin{array}{l}\text { public domain lands, and the rules for its use were } \\
\text { defined by the authority of the U.S. Government. } \\
\text { The PLSS has since been extended, following similar } \\
\text { rules, into non-public domain areas. }\end{array}$ \\
\hline
\end{tabular}




\section{Appendix 1. Predicate terms in Digital Line Graph (DLG) standard feature definitions._-Continued}

[The data analyzed in this table is based on the DLG standard. The text from the original documents was changed as little as possible and only for research purposes. As a result, the glossary definitions may appear to be breaking rules of grammar, but were arranged to help clarify semantic meanings. Feature type terms are listed in alphabetical order. Verbs appear in lowercase and prepositions appear in uppercase fonts. Inferred terms are presented within parentheses. ,-- no data]

\begin{tabular}{|c|c|c|c|}
\hline Term & Subject & Predicate & Object \\
\hline $\begin{array}{l}\text { Public_Land_Sur- } \\
\text { vey_System_Area }\end{array}$ & $\begin{array}{l}\text { An area of land which is subdivided } \\
\text { by the Public Land Survey System } \\
\text { (PLSS), and was originally created } \\
\text { on public domain lands, and the } \\
\text { rules for its use were }\end{array}$ & definedBY & $\begin{array}{l}\text { the authority of the U.S. Government. The PLSS has } \\
\text { since been extended, following similar rules, into } \\
\text { non-public domain areas. }\end{array}$ \\
\hline $\begin{array}{l}\text { Public_Land_Sur- } \\
\text { vey_System_Area }\end{array}$ & $\begin{array}{l}\text { An area of land which is subdivided } \\
\text { by the Public Land Survey System } \\
\text { (PLSS), and was originally created } \\
\text { on public domain lands, and the } \\
\text { rules for its use were defined by the } \\
\text { authority of the U.S. Government. } \\
\text { The PLSS has since been }\end{array}$ & extendedINTO & non-public domain areas. \\
\hline $\begin{array}{l}\text { Public_Land_Sur- } \\
\text { vey_System_Area }\end{array}$ & An area of land which is & subdividedBY & $\begin{array}{l}\text { the Public Land Survey System (PLSS), and was } \\
\text { originally created on public domain lands, and the } \\
\text { rules for its use were defined by the authority of } \\
\text { the U.S. Government. The PLSS has since been } \\
\text { extended, following similar rules, into non-public } \\
\text { domain areas. }\end{array}$ \\
\hline Racetrack & A course & laid_outFOR & racing. \\
\hline Railway & A train or trolley & runsON & a set of parallel rails. \\
\hline Railway_Yard & $\begin{array}{l}\text { An area provided with a system of } \\
\text { tracks and associated structures, }\end{array}$ & (is)WHERE & $\begin{array}{l}\text { railway trains are assembled, and railway cars are } \\
\text { switched, stored or serviced. }\end{array}$ \\
\hline Railway_Yard & An area & providedWITH & $\begin{array}{l}\text { a system of tracks and associated structures, where } \\
\text { railway trains are assembled, and railway cars are } \\
\text { switched, stored or serviced. }\end{array}$ \\
\hline Range & A chain & (composed)OF & mounts and/or ridges. \\
\hline Rapids & An area of swift current & (is) IN & $\begin{array}{l}\text { a stream or river, characterized by standing waves or } \\
\text { by boulders and rocks. }\end{array}$ \\
\hline Rapids & $\begin{array}{l}\text { An area of swift current in a stream } \\
\text { or river, }\end{array}$ & characterizedBY & standing waves or by boulders and rocks. \\
\hline Recreational_Slide & An amusement structure & consistingOF & $\begin{array}{l}\text { a smooth, usually inclined, surface or track for } \\
\text { sliding. }\end{array}$ \\
\hline Recreational_Slide & $\begin{array}{l}\text { An amusement structure consist- } \\
\text { ing of a smooth, usually inclined, } \\
\text { surface or track }\end{array}$ & usedFOR & sliding. \\
\hline Reef & A chain of rocks or coral & (is)AT, (is)NEAR & the surface of the water. \\
\hline Reservation & Bounded land & set_asideFOR & $\begin{array}{l}\text { a particular purpose, generally having certain use } \\
\text { restrictions. }\end{array}$ \\
\hline Reservoir & A constructed basin & formedTO & contain water or other liquids. \\
\hline Rest_Site & $\begin{array}{l}\text { A roadside area usually having } \\
\text { facilities }\end{array}$ & (intended)FOR & people and/or vehicles. \\
\hline Ridge & A & long and narrow & upland with steep sides. \\
\hline Road & An open way & usedFOR & the passage of vehicles. \\
\hline Rock & A concreted mass & (composed)OF & stony material. \\
\hline Route & A designated path & (goes)THROUGH & a road network. \\
\hline $\begin{array}{l}\text { Runway/Apron/ } \\
\text { Taxiway }\end{array}$ & An area & (is) $\mathrm{ON}$ & $\begin{array}{l}\text { land used by aircraft for takeoff, landing, parking or } \\
\text { access to runways. }\end{array}$ \\
\hline
\end{tabular}




\section{Appendix 1. Predicate terms in Digital Line Graph (DLG) standard feature definitions._-Continued}

[The data analyzed in this table is based on the DLG standard. The text from the original documents was changed as little as possible and only for research purposes. As a result, the glossary definitions may appear to be breaking rules of grammar, but were arranged to help clarify semantic meanings. Feature type terms are listed in alphabetical order. Verbs appear in lowercase and prepositions appear in uppercase fonts. Inferred terms are presented within parentheses. -- , no data]

\begin{tabular}{|c|c|c|c|}
\hline Term & Subject & Predicate & Object \\
\hline $\begin{array}{l}\text { Runway/Apron/ } \\
\text { Taxiway }\end{array}$ & An area on land & usedBY & $\begin{array}{l}\text { aircraft for takeoff, landing, parking or access to } \\
\text { runways. }\end{array}$ \\
\hline Sea/Ocean & The great body of salt water that & covers & much of the earth. \\
\hline $\begin{array}{l}\text { Sewage_Disposal_ } \\
\text { Plant }\end{array}$ & A group of structures & functioningAS & $\begin{array}{l}\text { a unit used for the disposal of domestic water-born } \\
\text { waste. }\end{array}$ \\
\hline $\begin{array}{l}\text { Sewage_Disposal_ } \\
\text { Plant }\end{array}$ & $\begin{array}{l}\text { A group of structures functioning } \\
\text { as a unit }\end{array}$ & usedFOR & the disposal of domestic water-born waste. \\
\hline Shopping_Center & A group of structures & usedFOR & the sale of products and services. \\
\hline Shoreline & A naturally occurring line of contact & (is)between & a body of water and the land. \\
\hline Shrubland & Area & coveredWITH & $\begin{array}{l}\text { plants that have persistent woody stems and a rela- } \\
\text { tively low growth habit, and that generally produce } \\
\text { several basal shoots instead of a single shoot. }\end{array}$ \\
\hline Sink/Rise & A stream & $\begin{array}{l}\text { disappears_under- } \\
\text { groundAT, reappears_- } \\
\text { at_the_surfaceAT, }\end{array}$ & the place. \\
\hline Ski_Jump & An inclined structure & consistingOF & a track from which snow skiers vault. \\
\hline Ski_Jump & snow skiers & vaultFROM & an inclined structure consisting of a track. \\
\hline Snag/Stump & $\begin{array}{l}\text { A firmly attached stem or trunk of } \\
\text { a tree }\end{array}$ & (is)NEAR & the surface of water. \\
\hline Sounding & The & $\begin{array}{l}\text { measured_depthOF, } \\
\text { chartered_depthOF }\end{array}$ & water below the hydrographic datum. \\
\hline $\begin{array}{l}\text { Special_Survey_ } \\
\text { Area }\end{array}$ & $\begin{array}{l}\text { An area of land within the original } \\
\text { holdings secured by the Federal } \\
\text { Government }\end{array}$ & (is)WITHIN & $\begin{array}{l}\text { Public Land states, subdivided by surveys that } \\
\text { involve unusual applications of, or departures from, } \\
\text { the rectangular system. The subdivided surveys often } \\
\text { carry out the provisions of a special legislative act. }\end{array}$ \\
\hline $\begin{array}{l}\text { Special_Survey_ } \\
\text { Area }\end{array}$ & $\begin{array}{l}\text { An area of land within the original } \\
\text { holdings secured by the Federal }\end{array}$ & $\begin{array}{l}\text { applicationsOF, } \\
\text { departuresFROM }\end{array}$ & $\begin{array}{l}\text { the rectangular system. The subdivided surveys often } \\
\text { carry out the provisions of a special legislative act. }\end{array}$ \\
\hline
\end{tabular}
Government (within Public Land states), subdivided by surveys that involve unusual 


\section{Appendix 1. Predicate terms in Digital Line Graph (DLG) standard feature definitions.—Continued}

[The data analyzed in this table is based on the DLG standard. The text from the original documents was changed as little as possible and only for research purposes. As a result, the glossary definitions may appear to be breaking rules of grammar, but were arranged to help clarify semantic meanings. Feature type terms are listed in alphabetical order. Verbs appear in lowercase and prepositions appear in uppercase fonts. Inferred terms are presented within parentheses. ,-- no data]

\begin{tabular}{|c|c|c|c|}
\hline Term & Subject & Predicate & Object \\
\hline $\begin{array}{l}\text { Special_Survey_ } \\
\text { Area }\end{array}$ & $\begin{array}{l}\text { An area of land within the original } \\
\text { holdings secured by the Federal } \\
\text { Government (within Public Land } \\
\text { states), subdivided by surveys that } \\
\text { involve unusual applications of, or } \\
\text { departures from, the rectangular sys- } \\
\text { tem. The subdivided surveys often }\end{array}$ & $\begin{array}{l}\text { carry_out_provision- } \\
\text { sOF }\end{array}$ & a special legislative act. \\
\hline $\begin{array}{l}\text { Special_Survey_ } \\
\text { Area }\end{array}$ & $\begin{array}{l}\text { An area of land within the original } \\
\text { holdings }\end{array}$ & securedBY & $\begin{array}{l}\text { the Federal Government (within Public Land states), } \\
\text { subdivided by surveys that involve unusual applica- } \\
\text { tions of, or departures from, the rectangular system. } \\
\text { The subdivided surveys often carry out the provisions } \\
\text { of a special legislative act. }\end{array}$ \\
\hline $\begin{array}{l}\text { Special_Survey_ } \\
\text { Area }\end{array}$ & $\begin{array}{l}\text { An area of land within the original } \\
\text { holdings secured by the Federal } \\
\text { Government (within Public Land } \\
\text { states), }\end{array}$ & subdividedBY & $\begin{array}{l}\text { surveys that involve unusual applications of, or } \\
\text { departures from, the rectangular system. The sub- } \\
\text { divided surveys often carry out the provisions of a } \\
\text { special legislative act. }\end{array}$ \\
\hline Special_Use_Zone & An area & WHERE & distinctive types of maritime activities occur. \\
\hline Special_Use_Zone & $\begin{array}{l}\text { Distinctive types of maritime } \\
\text { activities }\end{array}$ & occur(AT) & an area. \\
\hline $\begin{array}{l}\text { Special_Use_- } \\
\text { Zone_Limit }\end{array}$ & The limit of an area & usedFOR & distinctive types of maritime activities. \\
\hline Spillway & A $* * *$ passage & constructedFOR & surplus water to run over or around a dam. \\
\hline Spillway & $\begin{array}{l}\text { A constructed passage for surplus } \\
\text { water to }\end{array}$ & $\begin{array}{l}\text { runOVER, } \\
\text { runAROUND }\end{array}$ & a dam. \\
\hline Sports_Site & $\begin{array}{l}\text { A collection of facilities (open areas, } \\
\text { structures) }\end{array}$ & functioningAS & $\begin{array}{l}\text { a unit for the purpose of holding sporting events and } \\
\text { activities. }\end{array}$ \\
\hline Sports_Site & $\begin{array}{l}\text { Collection of facilities (open areas, } \\
\text { structures) functioning as a unit }\end{array}$ & usedFOR & the purpose of holding sporting events and activities. \\
\hline Spot_Elevation & $\begin{array}{l}\text { A point with a measured vertical } \\
\text { position of less than third order } \\
\text { accuracy, }\end{array}$ & measured_relativeTO & a reference datum. \\
\hline Spring/Seep & A place where water & issuesFROM & the ground naturally. \\
\hline State/Territory & First order division & (is) $\mathrm{OF}$ & a nation. \\
\hline Stream/River & A body & (composed)OF & flowing water. \\
\hline Submerged_Stream & An old river course & inundatedBY & an impounded water body. \\
\hline Substation & An ancillary facility & (is)ALONG & a powerline route for transforming electrical current. \\
\hline Substation & $\begin{array}{l}\text { An ancillary facility along a power- } \\
\text { line route }\end{array}$ & (used)FOR & transforming electrical current. \\
\hline Survey_Corner & A survey location that was originally & establishedFOR & $\begin{array}{l}\text { the purpose of referencing and/or defining the limits } \\
\text { of a survey. }\end{array}$ \\
\hline Survey_Corner & $\begin{array}{l}\text { A survey location that was origi- } \\
\text { nally established for the purpose of }\end{array}$ & $\begin{array}{l}\text { referencing_limitsOF, } \\
\text { defining_limitsOF }\end{array}$ & a survey. \\
\hline Survey_Line & The limiting line & (is)BETWEEN & public-land and/or private subdivisions. \\
\hline Swamp/Marsh & $\begin{array}{l}\text { A noncultivated, vegetated area } \\
\text { that is inundated or saturated for } \\
\text { a significant part of the year. The } \\
\text { vegetation is }\end{array}$ & adaptedFOR & life in saturated soil conditions. \\
\hline
\end{tabular}




\section{Appendix 1. Predicate terms in Digital Line Graph (DLG) standard feature definitions._- Continued}

[The data analyzed in this table is based on the DLG standard. The text from the original documents was changed as little as possible and only for research purposes. As a result, the glossary definitions may appear to be breaking rules of grammar, but were arranged to help clarify semantic meanings. Feature type terms are listed in alphabetical order. Verbs appear in lowercase and prepositions appear in uppercase fonts. Inferred terms are presented within parentheses. ,-- no data]

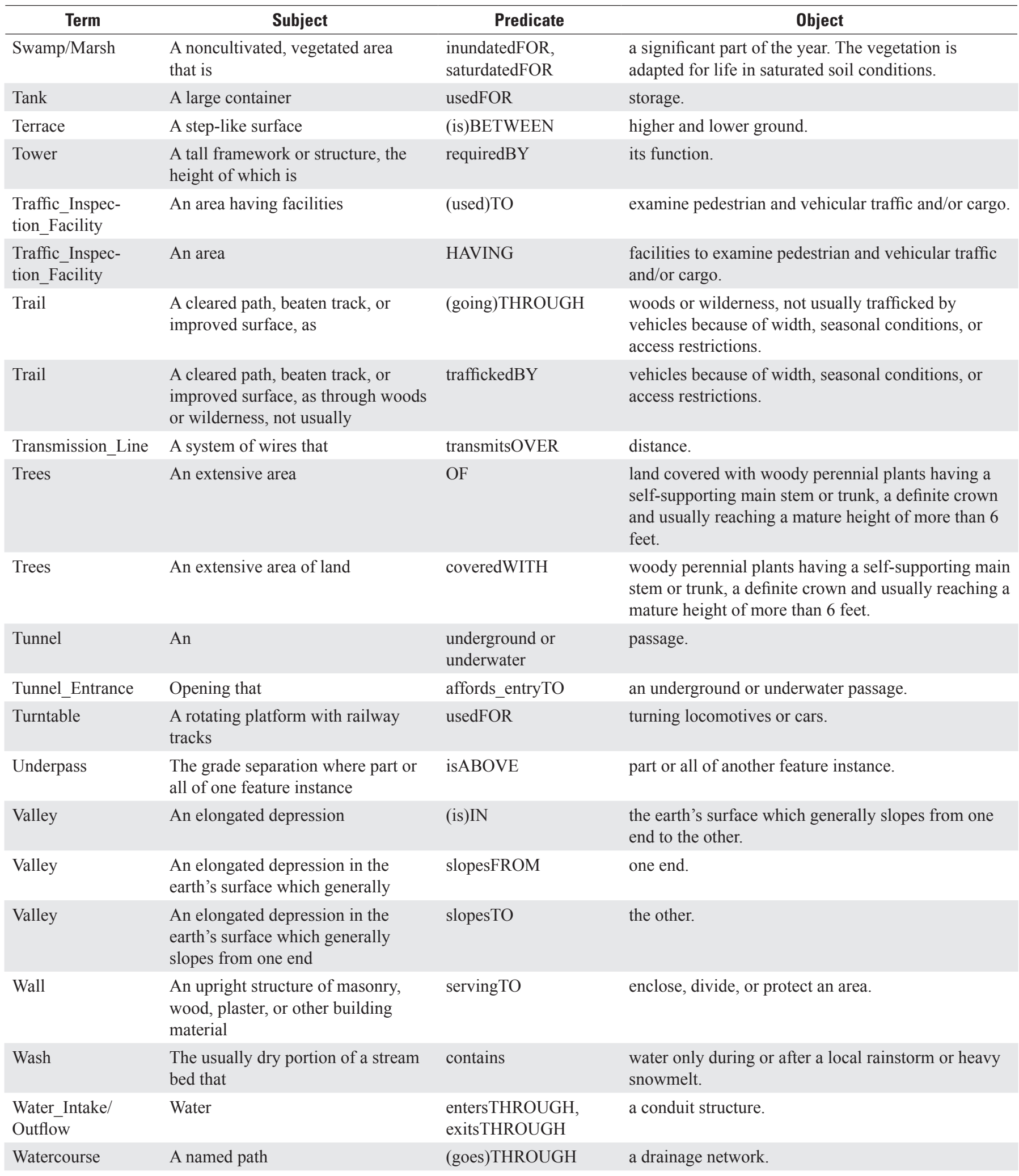




\section{Appendix 1. Predicate terms in Digital Line Graph (DLG) standard feature definitions.—Continued}

[The data analyzed in this table is based on the DLG standard. The text from the original documents was changed as little as possible and only for research purposes. As a result, the glossary definitions may appear to be breaking rules of grammar, but were arranged to help clarify semantic meanings. Feature type terms are listed in alphabetical order. Verbs appear in lowercase and prepositions appear in uppercase fonts. Inferred terms are presented within parentheses. ,-- no data]

\begin{tabular}{|c|c|c|c|}
\hline Term & Subject & Predicate & Object \\
\hline Waterfall & $\begin{array}{l}\text { A vertical or near vertical descent } \\
\text { of water }\end{array}$ & (descends)OVER & step or ledge in the bed of a river. \\
\hline Well & $\begin{array}{l}\text { A pit or hole dug or bored into the } \\
\text { earth }\end{array}$ & (used)FOR & the extraction of oil, water, other fluids, or gases. \\
\hline Well_Field & An area & WHERE & $\begin{array}{l}\text { petroleum and/or natural gas is or was removed from } \\
\text { the earth. }\end{array}$ \\
\hline Well_Field & $\begin{array}{l}\text { An area where petroleum and/or } \\
\text { natural gas is or was }\end{array}$ & removedFROM & the earth. \\
\hline Windmill & $\begin{array}{l}\text { A mill or other machine that runs on } \\
\text { the energy }\end{array}$ & generatedBY & $\begin{array}{l}\text { a wheel of adjustable blades or flats rotated by the } \\
\text { wind. }\end{array}$ \\
\hline Windmill & $\begin{array}{l}\text { A mill or other machine that runs on } \\
\text { the energy generated by a wheel of } \\
\text { adjustable blades or flats }\end{array}$ & rotatedBY & the wind. \\
\hline Windmill & A mill or other machine that & runsON & $\begin{array}{l}\text { the energy generated by a wheel of adjustable blades } \\
\text { or flats rotated by the wind. }\end{array}$ \\
\hline Wreck & $\begin{array}{l}\text { The hulk or the ruins of a disabled } \\
\text { vessel which is }\end{array}$ & attachedTO, foulOF & the bottom or cast up on the shore. \\
\hline
\end{tabular}




\section{Appendix 2. Predicate terms in USGS Geonames standard feature definitions.}

[The data analyzed in this table is based on the Geonames standard. The text from the original documents was changed as little as possible and only for research purposes. As a result, the glossary definitions may appear to be breaking rules of grammar, but were arranged to help clarify semantic meanings. Feature type terms are listed in alphabetical order. Verbs appear in lowercase and prepositions appear in uppercase fonts. Inferred terms are presented within parentheses. --, no data]

\begin{tabular}{|c|c|c|c|}
\hline Term & Subject & Predicate & Object \\
\hline Airport & Manmade facility & maintainedFOR & $\begin{array}{l}\text { the use of aircraft (airfield, airstrip, landing field, land- } \\
\text { ing strip). }\end{array}$ \\
\hline Area & $\begin{array}{l}\text { Any one of several areally extensive } \\
\text { natural features }\end{array}$ & not_includedIN & other categories (badlands, barren, delta, fan, garden). \\
\hline Arroyo & Water may occasionally & flowTHROUGH & watercourse or channel. \\
\hline Basin & Natural depression or relatively low area & enclosedBY & higher land (amphitheater, cirque, pit, sink). \\
\hline Bay & $\begin{array}{l}\text { A part of a body of water; a body of } \\
\text { water partly surrounded by land (arm, } \\
\text { bight, cove, estuary, gulf, inlet, sound). }\end{array}$ & enclosedBY & indentation of a coastline or shoreline. \\
\hline Beach & The sloping shore & (is)ALONG & a body of water. \\
\hline Beach & $\begin{array}{l}\text { The sloping shore along a body of water } \\
\text { that is washed by waves or tides and is } \\
\text { usually }\end{array}$ & coveredBY & sand or gravel (coast, shore, strand). \\
\hline Beach & $\begin{array}{l}\text { The sloping shore along a body of water } \\
\text { that is }\end{array}$ & washedBY & $\begin{array}{l}\text { waves or tides and is usually covered by sand or } \\
\text { gravel (coast, shore, strand). }\end{array}$ \\
\hline Bench & Area of relatively level land & (is) $\mathrm{ON}$ & $\begin{array}{l}\text { the flank of an elevation such as a hill, ridge, or moun- } \\
\text { tain where the slope of the land rises on one side and } \\
\text { descends on the opposite side (level). }\end{array}$ \\
\hline Bench & $\begin{array}{l}\text { Area of relatively level land on the flank } \\
\text { of an elevation such as a hill, ridge, or } \\
\text { mountain where the slope of the land } \\
\text { rises on one side and }\end{array}$ & descendsON & the opposite side (level). \\
\hline Bend & A & [curve]IN & a linear body of water (bottom, loop, meander). \\
\hline Bridge & Manmade structure & carryingACROSS & $\begin{array}{l}\text { a body of water or depression (causeway, overpass, } \\
\text { trestle). }\end{array}$ \\
\hline Building & $\begin{array}{l}\text { A manmade structure with walls and a } \\
\text { roof }\end{array}$ & (is)FOR & $\begin{array}{l}\text { protection of people and (or) materials, but not includ- } \\
\text { ing church, hospital, or school. }\end{array}$ \\
\hline Canal & Manmade waterway & usedBY & watercraft. \\
\hline Canal & Manmade waterway & usedFOR & $\begin{array}{l}\text { drainage, irrigation, mining, or water power (ditch, } \\
\text { lateal). }\end{array}$ \\
\hline Cape & Projection of land & extendingINTO & a body of water (lea, neck, peninsula, point). \\
\hline Cave & $\begin{array}{l}\text { Natural underground passageway or } \\
\text { chamber, or a hollowed out }\end{array}$ & [cavity]IN & the side of a cliff (cavern, grotto). \\
\hline Cemetery & A place or area & (used)FOR & $\begin{array}{l}\text { burying the dead (burial, burying ground, grave, } \\
\text { memorial garden). }\end{array}$ \\
\hline
\end{tabular}




\section{Appendix 2. Predicate terms in USGS Geonames standard feature definitions.—Continued}

[The data analyzed in this table is based on the Geonames standard. The text from the original documents was changed as little as possible and only for research purposes. As a result, the glossary definitions may appear to be breaking rules of grammar, but were arranged to help clarify semantic meanings. Feature type terms are listed in alphabetical order. Verbs appear in lowercase and prepositions appear in uppercase fonts. Inferred terms are presented within parentheses. --, no data]

\begin{tabular}{|c|c|c|c|}
\hline Term & Subject & Predicate & Object \\
\hline Census & $\begin{array}{l}\text { A statistical area delineated locally } \\
\text { specifically for the tabulation of Census } \\
\text { Bureau data (census designated place, } \\
\text { census county division, unorganized ter- } \\
\text { ritory, various types of American Indian/ } \\
\text { Alaska Native statistical areas). }\end{array}$ & [distinct]FROM & civil and populated place. \\
\hline Channel & Water & flowsTHROUGH & linear deep part of a body of water. \\
\hline Channel & $\begin{array}{l}\text { Linear deep part of a body of water } \\
\text { through which the main volume of water } \\
\text { flows and is frequently }\end{array}$ & usedAS & $\begin{array}{l}\text { a route for watercraft (passage, reach, strait, thorough- } \\
\text { fare, throughfare). }\end{array}$ \\
\hline Civil & $\begin{array}{l}\text { A political division formed for admin- } \\
\text { istrative purposes (borough, county, } \\
\text { incorporated place, municipio, parish, } \\
\text { town, township). }\end{array}$ & [distinct]FROM & census and populated place. \\
\hline Civil & A political division & formedFOR & $\begin{array}{l}\text { administrative purposes (borough, county, incorpo- } \\
\text { rated place, municipio, parish, town, township). }\end{array}$ \\
\hline Cliff & -- & (is) $[\mathrm{STEEP}]$ & $\begin{array}{l}\text { slope (bluff, crag, head, headland, nose, palisades, } \\
\text { precipice, promontory, rim, rimrock). }\end{array}$ \\
\hline Crater & Circular-shaped depression & (is) $\mathrm{AT}$ & $\begin{array}{l}\text { the summit of a volcanic cone or one on the surface } \\
\text { of the land caused by the impact of a meteorite; a } \\
\text { manmade depression caused by an explosion (caldera, } \\
\text { lua). }\end{array}$ \\
\hline Crater & A manmade depression & causedBY & an explosion (caldera, lua). \\
\hline Crossing & $\begin{array}{l}\text { A place where two or more routes of } \\
\text { transportation }\end{array}$ & formINTERSECTION & (overpass, underpass). \\
\hline Dam & Water barrier or embankment & builtACROSS & $\begin{array}{l}\text { the course of a stream or into a body of water to con- } \\
\text { trol and (or) impound the flow of water (breakwater, } \\
\text { dike, jetty). }\end{array}$ \\
\hline Dam & $\begin{array}{l}\text { Water barrier or embankment built } \\
\text { across the course of a stream or into a } \\
\text { body of water to }\end{array}$ & controlFLOW & of water (breakwater, dike, jetty). \\
\hline Falls & Perpendicular or very steep & fallin & the course of a stream (cascade, cataract, waterfall). \\
\hline Flat & Relative level area & (is)WITHIN & a region of greater relief (clearing, glade, playa). \\
\hline Forest & $\begin{array}{l}\text { Bounded area of woods, forest, or } \\
\text { grassland }\end{array}$ & $\begin{array}{l}\text { (is)[UNDER_ADMINIS- } \\
\text { TRATION_OF] }\end{array}$ & $\begin{array}{l}\text { a political agency (see "woods") (national forest, } \\
\text { national grasslands, State forest). }\end{array}$ \\
\hline
\end{tabular}




\section{Appendix 2. Predicate terms in USGS Geonames standard feature definitions._- Continued}

[The data analyzed in this table is based on the Geonames standard. The text from the original documents was changed as little as possible and only for research purposes. As a result, the glossary definitions may appear to be breaking rules of grammar, but were arranged to help clarify semantic meanings. Feature type terms are listed in alphabetical order. Verbs appear in lowercase and prepositions appear in uppercase fonts. Inferred terms are presented within parentheses. --, no data]

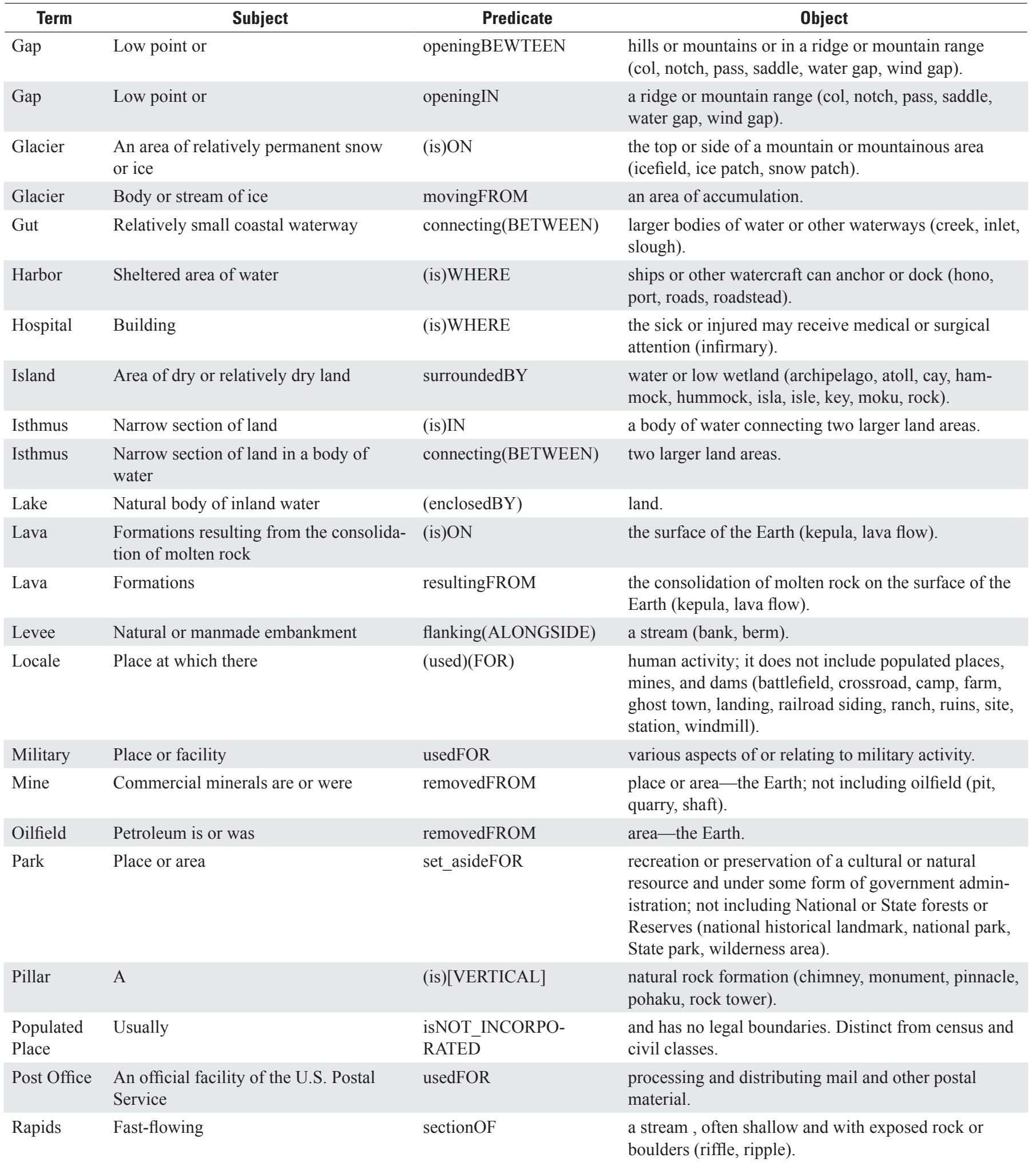




\section{Appendix 2. Predicate terms in USGS Geonames standard feature definitions.-Continued}

[The data analyzed in this table is based on the Geonames standard. The text from the original documents was changed as little as possible and only for research purposes. As a result, the glossary definitions may appear to be breaking rules of grammar, but were arranged to help clarify semantic meanings. Feature type terms are listed in alphabetical order. Verbs appear in lowercase and prepositions appear in uppercase fonts. Inferred terms are presented within parentheses. --, no data]

\begin{tabular}{|c|c|c|c|}
\hline Term & Subject & Predicate & Object \\
\hline Reserve & A tract of land & set_asideFOR & $\begin{array}{l}\text { a specific use (does not include forests, civil divisions, } \\
\text { parks). }\end{array}$ \\
\hline School & Building or group of buildings & usedAS & $\begin{array}{l}\text { an institution for study, teaching, and learning (acad- } \\
\text { emy, college, high school, university). }\end{array}$ \\
\hline Slope & A gently inclined & partOF & the Earth's surface (grade, pitch). \\
\hline Spring & Place & (is)WHERE & $\begin{array}{l}\text { underground water flows naturally to the surface of } \\
\text { the Earth (seep). }\end{array}$ \\
\hline Spring & Place where underground water & flowsTO & the surface of the Earth (seep). \\
\hline Stream & Linear body of water & flowingON & $\begin{array}{l}\text { the Earth's surface (anabranch, awawa, bayou, branch, } \\
\text { brook, creek, distributary, fork, kill, pup, rio, river, } \\
\text { run, slough). }\end{array}$ \\
\hline Summit & Prominent elevation & rising $A B O V E$ & $\begin{array}{l}\text { the surrounding level of the Earth's surface; does } \\
\text { not include pillars, ridges, or ranges (ahu, berg, bald, } \\
\text { butte, cerro, colina, cone, cumbre, dome, head, hill, } \\
\text { horn, knob, knoll, mauna, mesa, mesita, mound, } \\
\text { mount, mountain, peak, puu, rock, sugarloaf, table, } \\
\text { volcano). }\end{array}$ \\
\hline Tunnel & Linear underground passageway & openAT & both ends. \\
\hline Valley & Linear depression & (is)IN & $\begin{array}{l}\text { the Earth's surface that generally slopes from one end } \\
\text { to the other (barranca, canyon, chasm, cove, draw, } \\
\text { glen, gorge, gulch, gulf, hollow, ravine). }\end{array}$ \\
\hline Valley & $\begin{array}{l}\text { Linear depression in the Earth's surface } \\
\text { that generally }\end{array}$ & slopesFROM & $\begin{array}{l}\text { one end to the other (barranca, canyon, chasm, cove, } \\
\text { draw, glen, gorge, gulch, gulf, hollow, ravine). }\end{array}$ \\
\hline Well & Manmade shaft or hole & (is) IN & $\begin{array}{l}\text { the Earth's surface used to obtain fluid or gaseous } \\
\text { materials. }\end{array}$ \\
\hline Well & $\begin{array}{l}\text { Manmade shaft or hole in the Earth's } \\
\text { surface }\end{array}$ & usedTO & obtain fluid or gaseous materials. \\
\hline Woods & Small area & coveredWITH & $\begin{array}{l}\text { a dense growth of trees; does not include an area of } \\
\text { trees under the administration of a political agency } \\
\text { (see "forest"). }\end{array}$ \\
\hline
\end{tabular}




\section{Appendix 3. Predicate terms in Spatial Data Transfer Standard (SDTS) feature definitions.}

[The data analyzed in this table is based on the SDTS standard. The text from the original documents was changed as little as possible and only for research purposes. As a result, the glossary definitions may appear to be breaking rules of grammar, but were arranged to help clarify semantic meanings. Feature type terms are listed in alphabetical order. Verbs appear in lowercase and prepositions appear in uppercase fonts. Inferred terms are presented within parentheses. ,-- no data]

\begin{tabular}{|c|c|c|c|}
\hline Term & Subject & Predicate & Object \\
\hline Airport & A facility, either & (is) $\mathrm{ON}$ & $\begin{array}{l}\text { land or water, where aircraft can take off and land; } \\
\text { usually consists of hard-surfaced landing strips, a } \\
\text { control tower, hangars, and accommodations for pas- } \\
\text { sengers and cargo. }\end{array}$ \\
\hline Airport & A facility, either on land or water, & (is)WHERE & $\begin{array}{l}\text { aircraft can take off and land; usually consists of } \\
\text { hard-surfaced landing strips, a control tower, han- } \\
\text { gars, and accommodations for passengers and cargo. }\end{array}$ \\
\hline Airport & $\begin{array}{l}\text { A facility, either on land or water, } \\
\text { where aircraft can take off and } \\
\text { land; usually }\end{array}$ & consistsOF & $\begin{array}{l}\text { hard-surfaced landing strips, a control tower, han- } \\
\text { gars, and accomodations for passengers and cargo. }\end{array}$ \\
\hline Alluvium & $\begin{array}{l}\text { All unconsolidated fragmental } \\
\text { material }\end{array}$ & laid_downBY & a stream. \\
\hline Ammunition Dump & A military installation & usedFOR & the storage of explosives and other warlike stores. \\
\hline Antenna & A metallic appartatus & $\begin{array}{l}\text { forSENDING, } \\
\text { forRECEIVING }\end{array}$ & electro-magnetic waves. \\
\hline Antenna_Array & A & groupOF & directional antennas. \\
\hline Approachway & The airspace that aircraft & $\begin{array}{l}\text { approachTHROUGH, } \\
\text { leaveTHROUGH }\end{array}$ & a landing area. \\
\hline Arch & A curved structure & supportsOVER & an open space. \\
\hline Backwater & an area of calm water & unaffectedBY & the current of a stream. \\
\hline Bar & $\begin{array}{l}\text { A submerged or emerged mound, } \\
\text { ridge, or succession of ridges of } \\
\text { sand or other material }\end{array}$ & extendingACROSS & the bottom, and which may obstruct navigation. \\
\hline Basin & Any bowl-shaped depression & (is) IN & the surface of the land or ocean floor. \\
\hline Beach & $\begin{array}{l}\text { The gently sloping shore which is } \\
\text { washed by waves or tides, espe- } \\
\text { cially the parts }\end{array}$ & coveredBY & sand or pebbles. \\
\hline Beach & The gently sloping shore which & isWASHED & $\begin{array}{l}\text { by waves or tides, especially the parts covered by } \\
\text { sand or pebbles. }\end{array}$ \\
\hline Beacon & $\begin{array}{l}\text { A fixed signal, mark, or light and } \\
\text { associated facilities }\end{array}$ & erectedFOR & the guidance of mariners or airplane pilots. \\
\hline Berth & The & placeWHERE & a ship lies when at anchor secured to a pier or wharf. \\
\hline Bottom & $\begin{array}{l}\text { The portion of the ground surface } \\
\text { which }\end{array}$ & liesBELOW & water. \\
\hline Boundary & A nonphysical line & $\begin{array}{l}\text { indicatingLIMIT, } \\
\text { indicatingEXTENT }\end{array}$ & of an area or territory. \\
\hline Breakers & $\begin{array}{l}\text { A zone or region of waves break- } \\
\text { ing into foam as they }\end{array}$ & advanceTOWARD & the shore. \\
\hline Breakers & A zone or region of waves & breakingINTO & foam as they advance toward the shore. \\
\hline Breakwater & A structure & builtTO & $\begin{array}{l}\text { break the force of waves so as to protect a beach, } \\
\text { harbor, or other waterfront facility. }\end{array}$ \\
\hline Bridge & A structure erected to & carryOVER & $\begin{array}{l}\text { a depression or obstacle to carry traffic or some } \\
\text { facility such as a pipeline. }\end{array}$ \\
\hline Bridge & A structure & erectedOVER & $\begin{array}{l}\text { a depression or obstacle to carry traffic or some } \\
\text { facility such as a pipeline. }\end{array}$ \\
\hline
\end{tabular}




\section{Appendix 3. Predicate terms in Spatial Data Transfer Standard (SDTS) feature definitions.—Continued}

[The data analyzed in this table is based on the SDTS standard. The text from the original documents was changed as little as possible and only for research purposes. As a result, the glossary definitions may appear to be breaking rules of grammar, but were arranged to help clarify semantic meanings. Feature type terms are listed in alphabetical order. Verbs appear in lowercase and prepositions appear in uppercase fonts. Inferred terms are presented within parentheses. -- , no data]

\begin{tabular}{|c|c|c|c|}
\hline Term & Subject & Predicate & Object \\
\hline $\begin{array}{l}\text { Bridge_Superstruc- } \\
\text { ture }\end{array}$ & $\begin{array}{l}\text { Those elements of the bridge } \\
\text { structure which }\end{array}$ & areABOVE & the uppermost deck. \\
\hline Building_Complex & $\begin{array}{l}\text { A group of buldings and associ- } \\
\text { ated facilities }\end{array}$ & functioningTOGETHER & as a unit. \\
\hline Cableway & $\begin{array}{l}\text { A conveyor system in which car- } \\
\text { ries units run on wire cables }\end{array}$ & [strung]BETWEEN & supports. \\
\hline Cableway & $\begin{array}{l}\text { A conveyor system in which car- } \\
\text { rier units }\end{array}$ & runON & wire cables [strung] between supports. \\
\hline Campground & $\begin{array}{l}\text { The ground or area on which } \\
\text { tents, huts, etc. are }\end{array}$ & erectedFOR & temporary shelter. \\
\hline Cape & A relatively extensive land area & juttingINTO & $\begin{array}{l}\text { a water body, which prominently marks a change in } \\
\text { or interrupts notably the coastal trend of that water } \\
\text { body. }\end{array}$ \\
\hline Catchment & $\begin{array}{l}\text { A natural drainage area which } \\
\text { may coincide with a river basin, in } \\
\text { which the divides }\end{array}$ & directinto & a river. \\
\hline Catchment & An area & drainedBY & an single watercourse. \\
\hline Cave & A & $\begin{array}{l}\text { (is)NATURALLY } \\
\text { FORMED, (is)SUB- } \\
\text { TERRANEAN, (is) } \\
\text { OPEN }\end{array}$ & area or chamber. \\
\hline Cirque & A deep natural hollow & (is)NEAR & the crest of a mountain. \\
\hline Clearing & An open area & (is) $\mathrm{IN}$ & a forest. \\
\hline Cliff & A & $\begin{array}{l}\text { (is)HIGH, (is)STEEP, } \\
\text { (is)OVERHANGING }\end{array}$ & face of rock. \\
\hline Coast & $\begin{array}{l}\text { The general region of indefinite } \\
\text { width that }\end{array}$ & extendsFROM & $\begin{array}{l}\text { the sea inland to the first major change in terrain } \\
\text { features. }\end{array}$ \\
\hline Coast & $\begin{array}{l}\text { The general region of indefinite } \\
\text { width that }\end{array}$ & extendsTO & the first major change in terrain features. \\
\hline Continent & Earth's surface is & dividedINTO & one of the large, unbroken masses of land. \\
\hline Control_Point & A point of & (is)KNOWN & location. \\
\hline Crater & Circular-shaped depression & atSUMMIT & of a volcanic cone or on the surface of the land. \\
\hline Crater & $\begin{array}{l}\text { Circular-shaped depression at the } \\
\text { summit of a volcanic cone or }\end{array}$ & onSURFACE & of the land. \\
\hline
\end{tabular}




\section{Appendix 3. Predicate terms in Spatial Data Transfer Standard (SDTS) feature definitions._-Continued}

[The data analyzed in this table is based on the SDTS standard. The text from the original documents was changed as little as possible and only for research purposes. As a result, the glossary definitions may appear to be breaking rules of grammar, but were arranged to help clarify semantic meanings. Feature type terms are listed in alphabetical order. Verbs appear in lowercase and prepositions appear in uppercase fonts. Inferred terms are presented within parentheses. ,-- no data]

\begin{tabular}{|c|c|c|c|}
\hline Term & Subject & Predicate & Object \\
\hline Crevasse & A deep fissure & (is) $\mathrm{IN}$ & snow or ice. \\
\hline Crib & $\begin{array}{l}\text { A crate-like construction of logs } \\
\text { or beams, usually }\end{array}$ & filledWITH & $\begin{array}{l}\text { stones, placed in water as a free standing mooring } \\
\text { device or as the foundation of a pier or wharf. }\end{array}$ \\
\hline Crib & $\begin{array}{l}\text { A crate-like construction of logs } \\
\text { or beams, usually filled with } \\
\text { stones, }\end{array}$ & placedIN & $\begin{array}{l}\text { water as a free standing mooring device or as the } \\
\text { foundation of a pier or wharf. }\end{array}$ \\
\hline Cut & $\begin{array}{l}\text { An excavation of the Earth's } \\
\text { surface to provide }\end{array}$ & passageFOR & a road, railway, canal, etc. \\
\hline Dam & A barrier & constructedACROSS & $\begin{array}{l}\text { a watercourse to control the flow or raise the level of } \\
\text { water. }\end{array}$ \\
\hline Delta & A tract of alluvium & formedAT & $\begin{array}{l}\text { the mouth of a river where the deposition of some of } \\
\text { its load exceeds its rate of removal. }\end{array}$ \\
\hline Demilitariazed_Zone & An area & (isWHERE) & military activity is prohibited. \\
\hline Desert & A region & rendered_barrenBY & environmental extremes, especially by low rainfall. \\
\hline Dry_Dock & An artificial basin & fittedWITH & $\begin{array}{l}\text { gate or caisson into which a vessel may be floated } \\
\text { and from which the water may be pumped out to } \\
\text { expose the bottom of the vessel. }\end{array}$ \\
\hline Farm & $\begin{array}{l}\text { A tract of crop or grazing land, } \\
\text { as well as the group of buildings } \\
\text { with and often }\end{array}$ & (is)SURROUNDING & $\begin{array}{l}\text { a farmhouse, including barns, sheds, and other out- } \\
\text { buildings, used for agricultural production. }\end{array}$ \\
\hline Farm & $\begin{array}{l}\text { A tract of crop or grazing land, } \\
\text { as well as the group of buildings } \\
\text { with and often surrounding a } \\
\text { farmhouse, including barns, sheds, } \\
\text { and other outbuildings, }\end{array}$ & usedFOR & agricultural production. \\
\hline Fault & A fracture & (is) $\mathrm{IN}$ & $\begin{array}{l}\text { the Earth's crust with displacement on one side of } \\
\text { the fracture relative to the other. }\end{array}$ \\
\hline Fence & An enclosure or barrier & madeOF & $\begin{array}{l}\text { wire, rails, slats or other relatively light material, as } \\
\text { opposed to a wall which is of stone or other heavy } \\
\text { material. }\end{array}$ \\
\hline
\end{tabular}




\section{Appendix 3. Predicate terms in Spatial Data Transfer Standard (SDTS) feature definitions.—Continued}

[The data analyzed in this table is based on the SDTS standard. The text from the original documents was changed as little as possible and only for research purposes. As a result, the glossary definitions may appear to be breaking rules of grammar, but were arranged to help clarify semantic meanings. Feature type terms are listed in alphabetical order. Verbs appear in lowercase and prepositions appear in uppercase fonts. Inferred terms are presented within parentheses. ,-- no data]

\begin{tabular}{|c|c|c|c|}
\hline Term & Subject & Predicate & Object \\
\hline Filtration_Beds & An area & (is)CONTAINING & layers of material used to filter or aerate water. \\
\hline Filtration_Beds & $\begin{array}{l}\text { An area containing layers of } \\
\text { material }\end{array}$ & usedTO & filter or aerate water. \\
\hline Fish_Hatchery & A facility & usedFOR & $\begin{array}{l}\text { the spawning of fish which are subsequently used to } \\
\text { stock lakes and streams. }\end{array}$ \\
\hline Fish_Ladder & $\begin{array}{l}\text { A facility consisting of a series } \\
\text { of small pools each one slightly } \\
\text { higher than the preceding, }\end{array}$ & builtAROUND & a dam to enable fish to make their way upstream. \\
\hline Fish_Ladder & A facility & consistingOF & $\begin{array}{l}\text { a series of small pools each one slightly higher than } \\
\text { the preceding, built around a dam to enable fish to } \\
\text { make their way upstream. }\end{array}$ \\
\hline Fish_Trap & A device & usedTO & catch fish. \\
\hline Fishing_Ground & A water area & (usedFOR) & fishing. \\
\hline Flat & A level tract & lyingBELOW & $\begin{array}{l}\text { the surface of water, or alternately covered and left } \\
\text { bare by the tide. }\end{array}$ \\
\hline Flood_Plain & An area which is & subjectTO & periodic flooding. \\
\hline Ford & The shallow & partOF & a river which can be easily crossed. \\
\hline Fort & Place or position & (is)FORTIFIED & -- \\
\hline Fumarole & A hole & (is) IN & $\begin{array}{l}\text { the Earth's crust from which steam and gases are } \\
\text { emitted. }\end{array}$ \\
\hline Fumarole & Steam and gases & emittedFROM & a hole in the Earth's crust. \\
\hline Gantry & A frame structure & raisedON & $\begin{array}{l}\text { side supports so as to span over or around } \\
\text { something. }\end{array}$ \\
\hline Gantry & $\begin{array}{l}\text { A frame structure raised on side } \\
\text { supports so as to }\end{array}$ & $\begin{array}{l}\text { spanOVER, } \\
\text { spanAROUND }\end{array}$ & something. \\
\hline Gap & Low point or opening & (is)BETWEEN & hills or mountains or in a ridge or mountain range. \\
\hline Gap & $\begin{array}{l}\text { Low point or opening between } \\
\text { hills or mountains or }\end{array}$ & (is) IN & a ridge or mountain range. \\
\hline Gate & A structure that & mayBLOCK & an entrance or passageway. \\
\hline Geyser & $\begin{array}{l}\text { An intermittent fountain of hot } \\
\text { water ejected with force from a } \\
\text { hole }\end{array}$ & (is) IN & the Earth's crust. \\
\hline Geyser & $\begin{array}{l}\text { An intermittent fountain of hot } \\
\text { water }\end{array}$ & ejectedFROM & a hole in the Earth's crust. \\
\hline Golf_Course & An area & (is)FOR & the playing of golf. \\
\hline Grandstand & A usually roofed structure & (is)FOR & $\begin{array}{l}\text { viewing events and having tiers of seats for } \\
\text { spectators. }\end{array}$ \\
\hline Grassland & An uncultivated & areaOF & grass or grass-like vegetation. \\
\hline Grave & A place & (is)WITHIN & a graveyard used for burial. \\
\hline Grave & A place within a graveyard & usedFOR & burial. \\
\hline Ground & The solid & portionOF & the Earth up to and including the ground surface. \\
\hline Ground_Surface & The land & surfaceOF & the Earth, both exposed and underwater. \\
\hline Guard_Rail & $\begin{array}{l}\text { A strong fence or barrier to } \\
\text { prevent vehicles from leaving the } \\
\text { roadway, or }\end{array}$ & (used)FOR & people's safety. \\
\hline
\end{tabular}




\section{Appendix 3. Predicate terms in Spatial Data Transfer Standard (SDTS) feature definitions._Continued}

[The data analyzed in this table is based on the SDTS standard. The text from the original documents was changed as little as possible and only for research purposes. As a result, the glossary definitions may appear to be breaking rules of grammar, but were arranged to help clarify semantic meanings. Feature type terms are listed in alphabetical order. Verbs appear in lowercase and prepositions appear in uppercase fonts. Inferred terms are presented within parentheses. ,-- no data]

\begin{tabular}{|c|c|c|c|}
\hline Term & Subject & Predicate & Object \\
\hline Guard_Rail & A strong fence or barrier & (used)TO & $\begin{array}{l}\text { prevent vehicles from leaving the roadway, or for } \\
\text { people's safety. }\end{array}$ \\
\hline Harbor & An area of water & (is)WHERE & ships, planes or other watercraft can anchor or dock. \\
\hline Headwaters & The & upper_partOF & $\begin{array}{l}\text { a river system, denoting the upper basin and source } \\
\text { streams of a river. }\end{array}$ \\
\hline Hedge & A dense growth of shrubbery & plantedAS & a fence or boundary. \\
\hline Helipad & A transportation structure & usedFOR & the landing of helicopters. \\
\hline Hopper & $\begin{array}{l}\text { A top loading funnel-shaped } \\
\text { structure }\end{array}$ & (used)FOR & $\begin{array}{l}\text { temporary storage of loose materials which will be } \\
\text { dispensed from its bottom. }\end{array}$ \\
\hline Hopper & $\begin{array}{l}\text { A top loading funnel-shaped struc- } \\
\text { ture for temporary storage of loose } \\
\text { materials which will be }\end{array}$ & dispensedFROM & its bottom. \\
\hline Ice_Field & Large area & (composed)OF & permanent sea or land ice. \\
\hline Ice_Rink & A surface & (composed)OF & ice. \\
\hline Ice_Rink & A surface of ice & (used)FOR & ice skating. \\
\hline Iceberg & A large mass of detached land ice & (is) $\mathrm{IN}$ & the sea or stranded in shallow water. \\
\hline Indian_Reservation & An area & set_asideFOR & the use of an indian tribe or tribes. \\
\hline Inlet & The sea & opensINTO & the land. \\
\hline Inlet & A lake & opensINTO & its shore. \\
\hline $\begin{array}{l}\text { Inshore_Traf- } \\
\text { fic_Zone }\end{array}$ & A designated area & (is)BETWEEN & $\begin{array}{l}\text { the landward boundary of a traffic separation scheme } \\
\text { and the adjacent coast, intended for local traffic. }\end{array}$ \\
\hline $\begin{array}{l}\text { Inshore_Traf- } \\
\text { fic_Zone }\end{array}$ & $\begin{array}{l}\text { A designated area between the } \\
\text { landward boundary of a traffic } \\
\text { separation scheme and the adja- } \\
\text { cent coast, }\end{array}$ & intendedFOR & local traffic. \\
\hline Intersection & The & junctionOF & roads or tracks. \\
\hline Irrigation_System & A system & designedTO & supply land with water. \\
\hline Island & Area & (composed)OF & $\begin{array}{l}\text { dry or relatively dry land surrounded by water or low } \\
\text { wetland. }\end{array}$ \\
\hline Island & Area of dry or relatively dry land & surroundedBY & water or low wetland. \\
\hline Island_Cluster & A group & (composed)OF & islands. \\
\hline Isthmus & $\begin{array}{l}\text { Narrow section of land in a body } \\
\text { of water }\end{array}$ & (is)CONNECTING & two larger land areas. \\
\hline Isthmus & Narrow section of land & (is) IN & a body of water connecting two larger land areas. \\
\hline Lagoon & The sheet of water & (is)BETWEEN & an offshore reef, especially of coral and mainland. \\
\hline Lagoon & The sheet of water & (is)WITHIN & a ring or horseshoe shaped atoll. \\
\hline Lagoon & Sand or shingle banks & (isBETWEEN) & a sheet of salt water separated from the open sea. \\
\hline Lagoon & A sheet of salt water & separatedFROM & $\begin{array}{l}\text { the open sea by sand or shingle banks. The sheet of } \\
\text { water between an offshore reef, esp. of coral and } \\
\text { mainland. The sheet of water within a ring or horse- } \\
\text { shoe shaped atoll. }\end{array}$ \\
\hline Lake & Any standard body & (composed)OF & inland water. \\
\hline Landing_Place & A place & (used)FOR & $\begin{array}{l}\text { loading and unloading passengers or cargo to and } \\
\text { from water vessels. }\end{array}$ \\
\hline
\end{tabular}




\section{Appendix 3. Predicate terms in Spatial Data Transfer Standard (SDTS) feature definitions.—Continued}

[The data analyzed in this table is based on the SDTS standard. The text from the original documents was changed as little as possible and only for research purposes. As a result, the glossary definitions may appear to be breaking rules of grammar, but were arranged to help clarify semantic meanings. Feature type terms are listed in alphabetical order. Verbs appear in lowercase and prepositions appear in uppercase fonts. Inferred terms are presented within parentheses. ,-- no data]

\begin{tabular}{|c|c|c|c|}
\hline Term & Subject & Predicate & Object \\
\hline Lane & A prescribed course & (used)FOR & $\begin{array}{l}\text { ships or aircraft, or a strip delineated on a road to } \\
\text { accommodate a single line of automobiles; not to be } \\
\text { confused with the road itself. }\end{array}$ \\
\hline Lane & $\begin{array}{l}\text { A prescribed course for ships or } \\
\text { aircraft, or a strip delineated on } \\
\text { a road }\end{array}$ & (used)TO & $\begin{array}{l}\text { accommodate a single line of automobiles; not to be } \\
\text { confused with the road itself. }\end{array}$ \\
\hline Launching_Ramp & A transportation structure & usedFOR & launching boats. \\
\hline Lock & An enclosure & (is)IN & $\begin{array}{l}\text { a water body with gates at each end to raise or lower } \\
\text { vessels as they pass from one level to another. }\end{array}$ \\
\hline Lock & $\begin{array}{l}\text { An enclosure in a water body with } \\
\text { gates at each end }\end{array}$ & (used)TO & $\begin{array}{l}\text { raise or lower vessels as they pass from one level to } \\
\text { another. }\end{array}$ \\
\hline Marina & $\begin{array}{l}\text { A harbor facility for recreational } \\
\text { craft }\end{array}$ & (is)WHERE & supplies, repairs, and various services are available. \\
\hline Marina & A harbor facility & (used)FOR & $\begin{array}{l}\text { recreational craft where supplies, repairs, and vari- } \\
\text { ous services are available. }\end{array}$ \\
\hline Military_Base & $\begin{array}{l}\text { An area owned and operated by } \\
\text { the government }\end{array}$ & inWHICH (isWHERE) & various military activities take place. \\
\hline Military_Base & An area & ownedBY, operatedBY & $\begin{array}{l}\text { the government in which various military activities } \\
\text { take place. }\end{array}$ \\
\hline Military_Bunker & A military strong point, usually & partOF & an extensive fortification. \\
\hline Mine & An excavation & (is) IN & $\begin{array}{l}\text { the Earth for the purpose of extracting earth } \\
\text { materials. }\end{array}$ \\
\hline Mine_Field & $\begin{array}{l}\text { An area where explosive mines } \\
\text { have been anchored or sunk in } \\
\text { water or }\end{array}$ & buriedON & land. \\
\hline Missile_Site & An & areaFOR & housing and launching guided missiles. \\
\hline Mobile_Home & A trailer that & $\begin{array}{l}\text { isDWELLING, } \\
\text { isDESIGNED }\end{array}$ & without a permanent foundation. \\
\hline Mobile_Home_Park & An & areaFOR & the parking of inhabited mobile homes. \\
\hline Monument & A structure & erectedAS & a memorial. \\
\hline Mooring & The & placeWHERE & $\begin{array}{l}\text { a craft may be secured to the ground, wharf, pier, } \\
\text { post, or buoy. }\end{array}$ \\
\hline Mooring & The place where a craft may be & securedTO & the ground, wharf, pier, post, or buoy. \\
\hline Moraine & An & accumulationOF & $\begin{array}{l}\text { boulders, stones, or other debris carried and depos- } \\
\text { ited by a glacier. }\end{array}$ \\
\hline
\end{tabular}




\section{Appendix 3. Predicate terms in Spatial Data Transfer Standard (SDTS) feature definitions._-Continued}

[The data analyzed in this table is based on the SDTS standard. The text from the original documents was changed as little as possible and only for research purposes. As a result, the glossary definitions may appear to be breaking rules of grammar, but were arranged to help clarify semantic meanings. Feature type terms are listed in alphabetical order. Verbs appear in lowercase and prepositions appear in uppercase fonts. Inferred terms are presented within parentheses. --, no data]

\begin{tabular}{|c|c|c|c|}
\hline Term & Subject & Predicate & Object \\
\hline Morained & $\begin{array}{l}\text { An accumulation of boulders, } \\
\text { stones, or other debris }\end{array}$ & carriedBY, depositedBY & a glacier. \\
\hline Mount_Range & A series of & $\begin{array}{l}\text { (is)CONNECTED, (is) } \\
\text { ALIGNED }\end{array}$ & mountains or mountain ridges. \\
\hline Mount_Range & A & seriesOF & $\begin{array}{l}\text { connected and aligned mountains or mountain } \\
\text { ridges. }\end{array}$ \\
\hline Mouth & stream & $\begin{array}{l}\text { exitINTO, } \\
\text { dischargeINTO }\end{array}$ & another stream, lake, or sea. \\
\hline Mouth & The & $\begin{array}{l}\text { exitOF, } \\
\text { point_of_dischargeOF }\end{array}$ & a stream into another stream, lake, or sea. \\
\hline Oasis & A small, isolated, fertile or green & areaIN & a desert region, usually having a spring well. \\
\hline Offshore_Platform & A raised surface & locatedIN & a sea. \\
\hline Oil_Field & An & areaWHERE & petroleum is or was removed from the Earth. \\
\hline Oil_Field & An area where petroleum is or was & removedFROM & the Earth. \\
\hline Outdoor_Theater & $\begin{array}{l}\text { An outdoor area consisting of a } \\
\text { stage or other focal point, and an }\end{array}$ & areaWHERE & the audience can be seated. \\
\hline Outdoor_Theater & An outdoor area & consistingOF & $\begin{array}{l}\text { a stage or other focal point, and an area where the } \\
\text { audience can be seated. }\end{array}$ \\
\hline Overfalls & $\begin{array}{l}\text { Short breaking waves occurring } \\
\text { when a current passes over a shoal } \\
\text { or other submarine obstruction or }\end{array}$ & MEETS & a contrary wind or current. \\
\hline Overrun/Stopway & An & areaBEYOND & $\begin{array}{l}\text { the take-off runway able to support an airplane dur- } \\
\text { ing an aborted take-off. }\end{array}$ \\
\hline Park & A place or area & set_asideFOR & $\begin{array}{l}\text { recreation or preservation of a cultural or natural } \\
\text { resource. }\end{array}$ \\
\hline Parking_Area & An area & set_asideFOR & the parking of motor vehicles. \\
\hline Peak & The & summitOF & a mountain. \\
\hline Peninsula & A & bodyOF & land jutting out into and nearly surrounded by water. \\
\hline Peninsula & A body of land & $\begin{array}{l}\text { jutting_outINTO, } \\
\text { nearly_surroundedBY }\end{array}$ & water. \\
\hline Pier & $\begin{array}{l}\text { A structure built out into the } \\
\text { water, usually with its greatest } \\
\text { dimension }\end{array}$ & at_right_anglesTO & $\begin{array}{l}\text { the shore, forming a landing place or a place along- } \\
\text { side which vessels can lie. }\end{array}$ \\
\hline
\end{tabular}




\section{Appendix 3. Predicate terms in Spatial Data Transfer Standard (SDTS) feature definitions.—Continued}

[The data analyzed in this table is based on the SDTS standard. The text from the original documents was changed as little as possible and only for research purposes. As a result, the glossary definitions may appear to be breaking rules of grammar, but were arranged to help clarify semantic meanings. Feature type terms are listed in alphabetical order. Verbs appear in lowercase and prepositions appear in uppercase fonts. Inferred terms are presented within parentheses. ,-- no data]

\begin{tabular}{|c|c|c|c|}
\hline Term & Subject & Predicate & Object \\
\hline Pier & A structure & built_outINTO & $\begin{array}{l}\text { the water, usually with its greatest dimension at right } \\
\text { angles to the shore, forming a landing place or a } \\
\text { place alongside which vessels can lie. }\end{array}$ \\
\hline Pier & $\begin{array}{l}\text { A structure built out into the } \\
\text { water, usually with its greatest } \\
\text { dimension at right angles to the } \\
\text { shore, }\end{array}$ & placeALONGSIDE & which vessels can lie. \\
\hline Piling & A set of posts & forcedINTO & $\begin{array}{l}\text { the earth to serve as a support, as for a pier, or to } \\
\text { resist lateral pressure. }\end{array}$ \\
\hline Piling & A & setOF & $\begin{array}{l}\text { posts forced into the earth to serve as a support, as } \\
\text { for a pier, or to resist lateral pressure. }\end{array}$ \\
\hline Piling & $\begin{array}{l}\text { A set of posts forced into the earth } \\
\text { to serve as a support, as for a pier, } \\
\text { or }\end{array}$ & to_resist & lateral pressure. \\
\hline Piling & A set of posts forced into the earth & to_serveAS & a support, as for a pier, or to resist lateral pressure. \\
\hline Pilot_Waters & Areas & IN_WHICH & the services of a marine pilot are essential. \\
\hline Pinnacle & A tall, slender, spire-shaped rock & projectingFROM & a level or more gently sloping surface. \\
\hline Place & An & areaWITH & definite or indefinite boundaries. \\
\hline Plain & A & regionOF & $\begin{array}{l}\text { general uniform slope, comparatively level, and of } \\
\text { considerable extent. }\end{array}$ \\
\hline Plateau & $\begin{array}{l}\text { An elevated and comparatively } \\
\text { level }\end{array}$ & expanseOF & land. \\
\hline Plunge_Pool & $\begin{array}{l}\text { A hollow eroded by the force of } \\
\text { the falling water }\end{array}$ & atBASE_OF & a waterfall, particularly by the eddying effect. \\
\hline Plunge_Pool & A hollow & erodedBY & $\begin{array}{l}\text { the force of the falling water at the base of a water- } \\
\text { fall, particularly by the eddying effect. }\end{array}$ \\
\hline Polyna & Any water area & enclosedIN & $\begin{array}{l}\text { pack ice, other than a lead, not large enough to be } \\
\text { called open water. When frozen over, a polyna } \\
\text { becomes an ice skylight from the point of view } \\
\text { of the submariner. Also called BIG CLEARING, } \\
\text { CLEARING, GLADE, ICE CLEARING, POOL, } \\
\text { REGIONAL CLEARING. }\end{array}$ \\
\hline Port & $\begin{array}{l}\text { A landing place provided with } \\
\text { terminal and transfer facilities }\end{array}$ & (used)FOR & $\begin{array}{l}\text { loading and discharging cargo or passengers, usually } \\
\text { located in a harbor. }\end{array}$ \\
\hline Port & $\begin{array}{l}\text { A landing place provided with } \\
\text { terminal and transfer facilities for } \\
\text { loading and discharging cargo or } \\
\text { passengers, usually }\end{array}$ & locatedIN & a harbor. \\
\hline Port & A landing place & providedWITH & $\begin{array}{l}\text { terminal and transfer facilities for loading and } \\
\text { discharging cargo or passengers, usually located in } \\
\text { a harbor. }\end{array}$ \\
\hline Post & $\begin{array}{l}\text { A long relatively slender, and } \\
\text { generally round }\end{array}$ & pieceOF & wood or other material. \\
\hline Pump_Out_Facility & A & holding_placeWHERE & ship's bilges and cargo are pumped. \\
\hline Pyramid & $\begin{array}{l}\text { An ancient structure having a } \\
\text { broad base with sides }\end{array}$ & narrowingTOWARDS & the top. \\
\hline Pyramid & An ancient & structureHAVING & a broad base with sides narrowing towards the top. \\
\hline
\end{tabular}




\section{Appendix 3. Predicate terms in Spatial Data Transfer Standard (SDTS) feature definitions._Continued}

[The data analyzed in this table is based on the SDTS standard. The text from the original documents was changed as little as possible and only for research purposes. As a result, the glossary definitions may appear to be breaking rules of grammar, but were arranged to help clarify semantic meanings. Feature type terms are listed in alphabetical order. Verbs appear in lowercase and prepositions appear in uppercase fonts. Inferred terms are presented within parentheses. ,-- no data]

\begin{tabular}{|c|c|c|c|}
\hline Term & Subject & Predicate & Object \\
\hline Quicksand & $\begin{array}{l}\text { A bed of loose sand mixed with } \\
\text { water }\end{array}$ & formingMASS & that yields easily to pressure. \\
\hline Quicksand & A bed of loose sand & mixedWITH & $\begin{array}{l}\text { water forming a soft, shifting mass that yields easily } \\
\text { to pressure. }\end{array}$ \\
\hline Racetrack & A course & laid_outFOR & racing. \\
\hline Radar_Dome & A dome shaped structure & usedTO & protect the antenna of a radar installation. \\
\hline Radar_Reflector & A device & $\begin{array}{l}\text { capableOF, } \\
\text { intendedFOR }\end{array}$ & reflecting radar signals. \\
\hline Railway & $\begin{array}{l}\text { A permanent way having one or } \\
\text { more rails which provides a track }\end{array}$ & (used)FOR & cars. \\
\hline Railway_Yard & $\begin{array}{l}\text { An area provided with a system } \\
\text { of tracks }\end{array}$ & (is)WHERE & $\begin{array}{l}\text { railroad trains are made up and cars are switched, } \\
\text { stored, or serviced. }\end{array}$ \\
\hline Railway_Yard & $\begin{array}{l}\text { An area provided with a system of } \\
\text { tracks where railroad trains }\end{array}$ & areMADE_UP & -- \\
\hline Railway_Yard & $\begin{array}{l}\text { An area provided with a system } \\
\text { of tracks where railroad trains are } \\
\text { made up and cars }\end{array}$ & $\begin{array}{l}\text { areSWITCHED, } \\
\text { areSTORED, } \\
\text { areSERVICED }\end{array}$ & -- \\
\hline Railway_Yard & An area & providedWITH & $\begin{array}{l}\text { a system of tracks where railroad trains are made up } \\
\text { and cars are switched, stored, or serviced. }\end{array}$ \\
\hline Rapids & $\begin{array}{l}\text { An area of broken, fast flowing } \\
\text { water in a stream, }\end{array}$ & (is)WHERE & $\begin{array}{l}\text { the slope of the bed increases (but without a promi- } \\
\text { nent break of slope which might result in a water- } \\
\text { fall), or where a gently dipping bar of harder rock } \\
\text { outcrops. }\end{array}$ \\
\hline Rapids & An & areaOF & $\begin{array}{l}\text { broken, fast flowing water in a stream, where the } \\
\text { slope of the bed increases (but without a prominent } \\
\text { break of slope which might result in a waterfall), or } \\
\text { where a gently dipping bar of harder rock outcrops. }\end{array}$ \\
\hline Reef & $\begin{array}{l}\text { A ridge of rocks, lying near the } \\
\text { surface of the sea, which may be } \\
\text { visible at low tide, but is usually }\end{array}$ & coveredBY & water. \\
\hline Reef & A ridge of rocks, & lyingNEAR & $\begin{array}{l}\text { the surface of the sea, which may be visible at low } \\
\text { tide, but is usually covered by water. }\end{array}$ \\
\hline Reef & $\begin{array}{l}\text { A ridge of rocks, lying near the } \\
\text { surface of the sea, which may be }\end{array}$ & visibleAT & low tide, but is usually covered by water. \\
\hline Refueling_Track & Airspace & designatedFOR & conducting aerial refueling. \\
\hline Reserve & A tract of land & set_asideFOR & a specific use. \\
\hline Restricted_Area & An area of air, land, or water & inWHICH (isWHERE) & $\begin{array}{l}\text { travel or other activities are subject to specified } \\
\text { conditions or constraints. }\end{array}$ \\
\hline Revetment & $\begin{array}{l}\text { A facing, other than a wall, of } \\
\text { stone, concrete, wood, etc., }\end{array}$ & builtTO & sustain an embankment. \\
\hline Ridge & A long and narrow upland & WITH & steep sides. \\
\hline Ridge_Line & The line & SEPARATING & drainage basins. \\
\hline Rig & Vertical structure & fittedFOR & drilling or lifting operations. \\
\hline Road & An open way & (used)FOR & the passage of vehicles, persons, or animals on land. \\
\hline
\end{tabular}




\section{Appendix 3. Predicate terms in Spatial Data Transfer Standard (SDTS) feature definitions.—Continued}

[The data analyzed in this table is based on the SDTS standard. The text from the original documents was changed as little as possible and only for research purposes. As a result, the glossary definitions may appear to be breaking rules of grammar, but were arranged to help clarify semantic meanings. Feature type terms are listed in alphabetical order. Verbs appear in lowercase and prepositions appear in uppercase fonts. Inferred terms are presented within parentheses. ,-- no data]

\begin{tabular}{|c|c|c|c|}
\hline Term & Subject & Predicate & Object \\
\hline Rock & $\begin{array}{l}\text { An isolated rocky formation or } \\
\text { a single large stone, usually one } \\
\text { constituting a }\end{array}$ & dangerTO & $\begin{array}{l}\text { navigation. It may be always submerged, always } \\
\text { uncovered, or alternately covered and uncovered by } \\
\text { the tide. }\end{array}$ \\
\hline Rock & $\begin{array}{l}\text { An isolated rocky formation or } \\
\text { a single large stone, usually one } \\
\text { constituting a danger to naviga- } \\
\text { tion. It may be always }\end{array}$ & $\begin{array}{l}\text { submergedBY, uncov- } \\
\text { eredBY, coveredBY }\end{array}$ & the tide. \\
\hline Roundabout & -- & areaOF & $\begin{array}{l}\text { water subject to a routing measure restricting ship } \\
\text { movement to a counter-clockwise direction. }\end{array}$ \\
\hline Roundabout & $\begin{array}{l}\text { Area of water subject to a routing } \\
\text { measure }\end{array}$ & $\begin{array}{l}\text { restrictingSHIP_MOVE- } \\
\text { MENT }\end{array}$ & to a counter-clockwise direction. \\
\hline Runway & A straight path & usedFOR & landing, taxiing, and take-off of aircraft. \\
\hline Salt_Pan & An & areaOF & salt deposits. \\
\hline Sea & The great & bodyOF & salt water of the oceans. \\
\hline Shaft & A long narrow passage & sunkIN & the earth. \\
\hline Shingle & A & collectionOF & loose pebbles on the shore of the sea or a lake. \\
\hline Shingle & A collection of loose pebbles & onSHORE & of the sea or a lake. \\
\hline Shipyard & A yard or & areaWHERE & ships are built or repaired. \\
\hline Shore & $\begin{array}{l}\text { That part of the land in immedi- } \\
\text { ate contact with a body of water } \\
\text { including the }\end{array}$ & areaBETWEEN & high and low water lines. \\
\hline Shore & That part of the land on immediate & contactWITH & $\begin{array}{l}\text { a body of water including the area between high and } \\
\text { low water lines. }\end{array}$ \\
\hline Shore & That & partOF & $\begin{array}{l}\text { the land in immediate contact with a body of water } \\
\text { including the area between high and low water lines }\end{array}$ \\
\hline Shoreline & The & $\begin{array}{l}\text { line_of_contactBE- } \\
\text { TWEEN }\end{array}$ & a body of water and the land. \\
\hline Sign & $\begin{array}{l}\text { A roadway associated feature } \\
\text { which }\end{array}$ & $\begin{array}{l}\text { providesINFORMA- } \\
\text { TION }\end{array}$ & to people passing. \\
\hline Ski_Area & An area & usedFOR & skiing. \\
\hline Ski_Jump & A ramp & usedFOR & ski jumping. \\
\hline Snag & A stem or trunk of a tree & $\begin{array}{l}\text { aboveSURFACE, } \\
\text { belowSURFACE }\end{array}$ & of the water. \\
\hline Snag & A & stemOF, trunkOF & a tree above or below the surface of the water. \\
\hline Snowfield & A region of permanent snow & $\mathrm{IN}$ & mountainous areas or high latitudes. \\
\hline Snowfield & A & regionOF & $\begin{array}{l}\text { permanent snow in mountainous areas or high } \\
\text { latitudes. }\end{array}$ \\
\hline Solar_Panel & A unit of solar cells & forCONVERTING & sunlight into electrical energy or heat. \\
\hline Sports_Field & A field & onWHICH & sporting activities are carried out. \\
\hline Spring & The place & (is)WHERE & water issues from the ground naturally. \\
\hline Spring & The place where water & issuesFROM & the ground naturally. \\
\hline Stadium & Large often unroofed structure & inWHICH (isWHERE) & athletic events are held. \\
\hline Stockyard & An enclosed area & inWHICH (isWHERE) & livestock are temporarily kept. \\
\hline
\end{tabular}




\section{Appendix 3. Predicate terms in Spatial Data Transfer Standard (SDTS) feature definitions._-Continued}

[The data analyzed in this table is based on the SDTS standard. The text from the original documents was changed as little as possible and only for research purposes. As a result, the glossary definitions may appear to be breaking rules of grammar, but were arranged to help clarify semantic meanings. Feature type terms are listed in alphabetical order. Verbs appear in lowercase and prepositions appear in uppercase fonts. Inferred terms are presented within parentheses. ,-- no data]

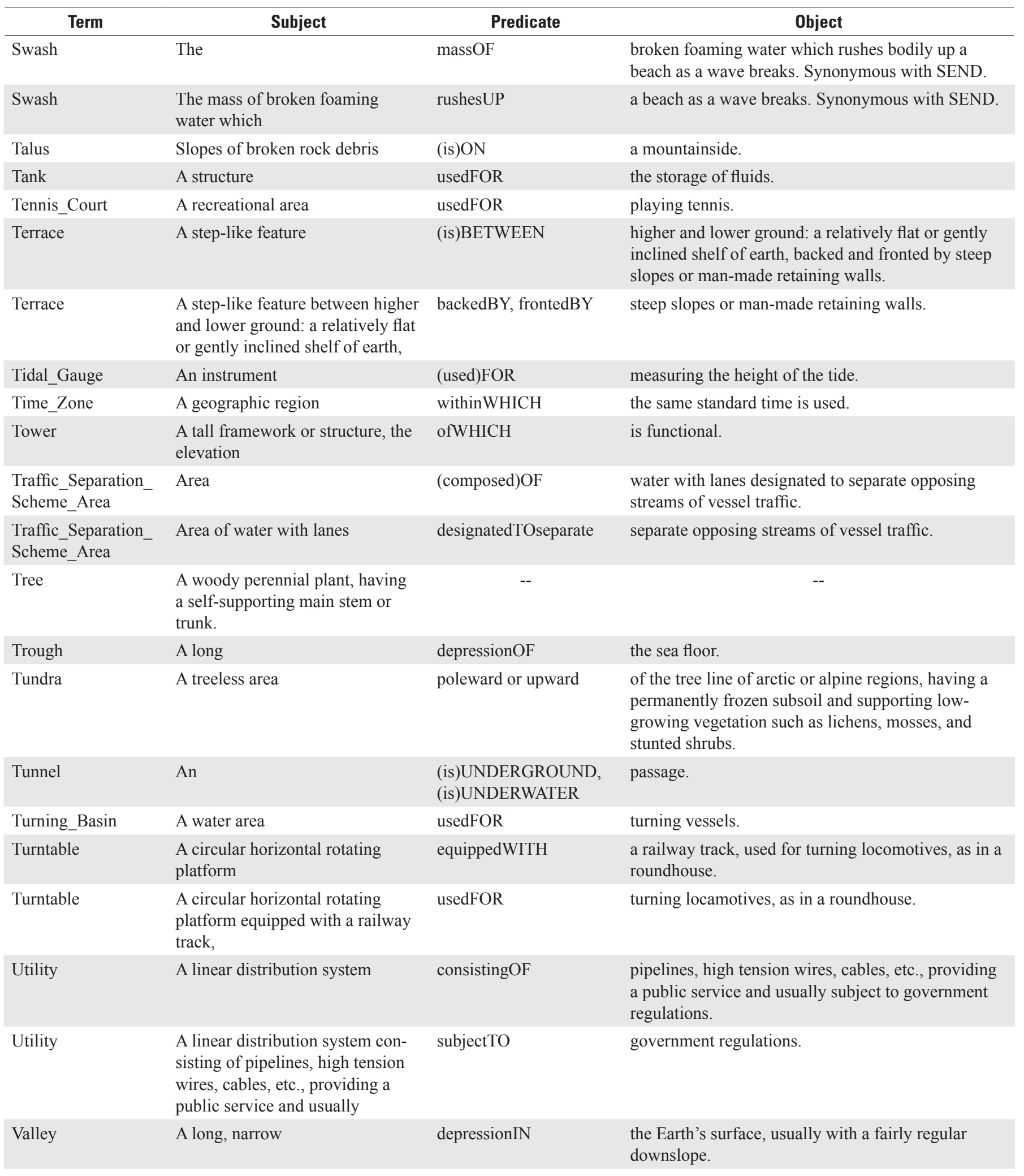




\section{Appendix 3. Predicate terms in Spatial Data Transfer Standard (SDTS) feature definitions._-Continued}

[The data analyzed in this table is based on the SDTS standard. The text from the original documents was changed as little as possible and only for research purposes. As a result, the glossary definitions may appear to be breaking rules of grammar, but were arranged to help clarify semantic meanings. Feature type terms are listed in alphabetical order. Verbs appear in lowercase and prepositions appear in uppercase fonts. Inferred terms are presented within parentheses. ,-- no data]

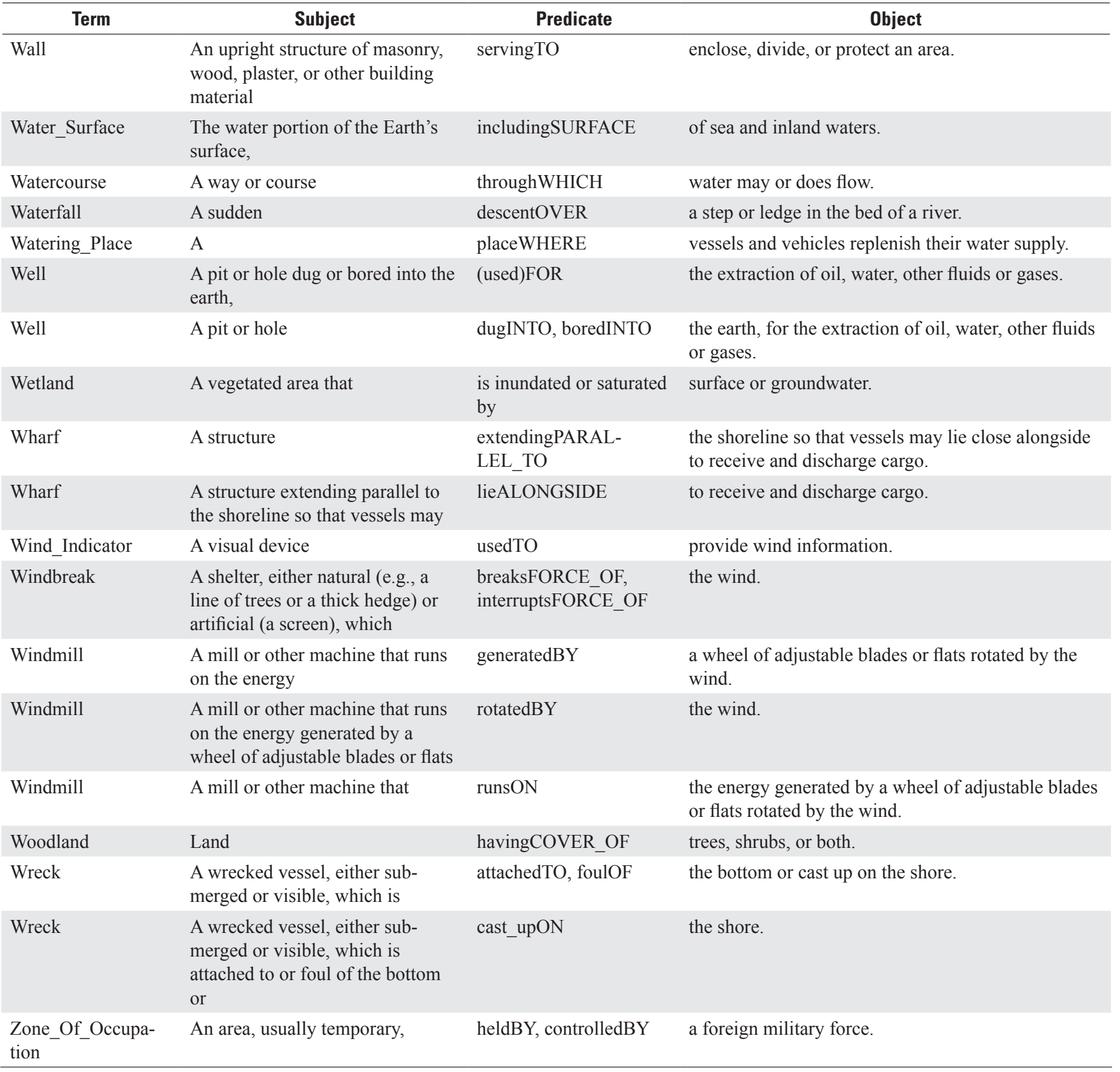


Publishing support provided by:

Rolla Publishing Service Center

For more information concerning this publication, contact:

Director, USGS Center of Excellence for Geospatial Information

Science (CEGIS)

1400 Independence Road

Rolla, M0 65401

(573) 308-3837

Or visit the CEGIS Web site at:

http://cegis.usgs.gov 



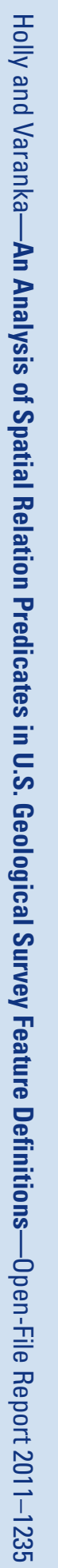

